Portland State University

PDXScholar

2016

\title{
A Numerical Modeling Investigation on Calving and the Recession of South Cascade Glacier
}

Annika Noel Horlings

Portland State University

Follow this and additional works at: https://pdxscholar.library.pdx.edu/honorstheses

Let us know how access to this document benefits you.

\section{Recommended Citation}

Horlings, Annika Noel, "A Numerical Modeling Investigation on Calving and the Recession of South Cascade Glacier" (2016). University Honors Theses. Paper 247.

https://doi.org/10.15760/honors.307

This Thesis is brought to you for free and open access. It has been accepted for inclusion in University Honors Theses by an authorized administrator of PDXScholar. Please contact us if we can make this document more accessible: pdxscholar@pdx.edu. 


\title{
A Numerical Modeling Investigation on Calving and the Recession of South Cascade Glacier
}

\author{
by \\ Annika Noel Horlings \\ An undergraduate honors thesis submitted in partial fulfillment of the \\ requirements for the degree of \\ Bachelor of Science \\ in \\ University Honors \\ and \\ Geology
}

\begin{abstract}
Primary Thesis Advisor
Andrew G. Fountain
\end{abstract}

Secondary Thesis Advisor

Maxwell L. Rudolph

Portland State University

2016 


\begin{abstract}
Retreat of South Cascade Glacier has been well documented since 1957. Despite this, little research has examined why South Cascade Glacier has receded more rapidly than other glaciers in the North Cascades region of Washington State during the last century. The purpose of this thesis is to determine whether calving associated with the proglacial South Cascade Lake significantly influenced the glacier's retreat. A simple numerical model using documented and projected historical net mass balances, bed configuration data, and lake basin data is used to approximate the recession of South Cascade Glacier during the last century. To evaluate the influence of calving on the glacier's recession, we simulate the glacier with and without calving losses. Experiments show that calving through the proglacial lake appears to have very little influence on the overall length and thickness of the glacier, however an improved calving equation is necessary to verify this result. Overall, climatic variations expressed through the ELA show to be more important than the effect of calving on changing the size of South Cascade Glacier.
\end{abstract}




\section{Contents}

1. Introduction

1.1. Glaciers and Climate Change

1.2 Glaciers of the North Cascades Range

1.3. South Cascade Glacier

2. Methodology

2.1. The Numerical Model: The Equations and Other Basics

2.2 Model Adaptations

2.2a General Adaptions

2.2b Bed Elevation

2.2c Shape Factor

2.2d Mass Balance

2.2e Calving

3. Experiments with the Numerical Model

3.1 Accuracy of the Model

3.2 Model Calibration

3.3 Sensitivity of the model

3.4 Simulating South Cascade Glacier
A. Simulating 1940 to 1964
B. Simulating 1940 to 2007
C. Simulating 1890 to 2007

4. Conclusion 


\section{Introduction}

Glacier response to changes in climate represents a long standing area of study in the geosciences, including those focused on glaciers of the North Cascades. What most studies have not investigated and considered as an important contributor to the past and present recession of certain valley glaciers is the influence of freshwater calving. This is somewhat surprising since calving has been identified as an important ablation process for water-terminating glaciers and a complex influencer in glacier dynamics (Benn et al., 2007a; Warren et al., 1995). South Cascade Glacier of the North Cascades Range has retreated more rapidly than most glaciers in the region (Fountain, 2015), however little study into the causes of this has occurred. We have observed that South Cascade Glacier is one of the few glaciers here to have a proglacial lake. This prompts us to ask the question: is calving the cause of the glacier's abnormally rapid retreat? Through the use of long-term field records and numerical modeling, we can investigate the causes of past glacier behavior with the hope of anticipating future glacier behavior. This project aims to examine the relationship between calving, climate variations, and the response of South Cascade Glacier, and ultimately to determine whether calving has greatly influenced South Cascade Glacier's recession.

\subsection{Glaciers and Climate Change}

Glaciers are sensitive to small changes in climate (Nye, 1960). Changes in climate cause temporal and spatial variations of a glacier's mass balance; changes in the glacier's velocity, thickness, and size occur in response to these variations in mass balance (Meier and Tangborn, 1965). However, the particular response of a glacier to a climatic variation is also result of features specific to the glacier, such as its geometry (Oerlemans et al., 1998). Understanding glaciers' response to climate change is essential to the world today. Besides being fascinating, glaciers are an important influence on humans in relation to water resources, geological hazards, and sea level rise, (Oerlemans, 2001). Many locations around the world rely on glacier meltwater as a source of water, and outbursts of glacier-dammed lakes present potential for large destruction (Oerlemans, 2001). Perhaps the most globally extending influence is 
glaciers' significant and accelerating contribution to sea level rise (Meier et al., 2007). Even though they hold substantially less water than the ice sheets of Greenland or Antarctica, valley glaciers and ice caps alone have contributed to $60 \%$ of the ice loss that has caused an increase in eustatic global sea level (Oerlemans, 2001; Meier et al., 2007). Studying glaciers and changes in climate, and the complexities of glacier response, represents a long standing area of interest for scientists and remains an integral yet challenging field of study (Meier and Tangborn, 1965).

\subsection{Glaciers of the North Cascades Range}

Although they have had periods of advance (Meier et al., 1971), research shows that all North Cascade glaciers are presently in a state of retreat (Pelto, 2006). Cause of this behavior has been attributed primarily to regional climate shifts, as illustrated by the overall similar patterns of recent mass balance changes for all North Cascade glaciers (Pelto, 2006). However, the response time of individual glaciers, or "the time taken [for a glacier] to approach a new steady state for a given climate-driven mass balance change," (Pelto and Hedlund, 2001) has not been uniform across the North Cascades region. Response times are governed by individual glacier characteristics such as slope, thickness, crevassing, and terminus position (Pelto and Hedlund, 2001). In other words, the regional effects of climate change experienced by North Cascade glaciers influence mass balance change universally, however the individual responses caused by the mass balance changes vary according to physical characteristics of the glaciers (Pelto and Hedlund, 2001; Pelto, 2006). Although most North Cascade glaciers have been and are currently retreating (Pelto, 2006), South Cascade Glacier has receded more rapidly than most (Fountain, 2015). 


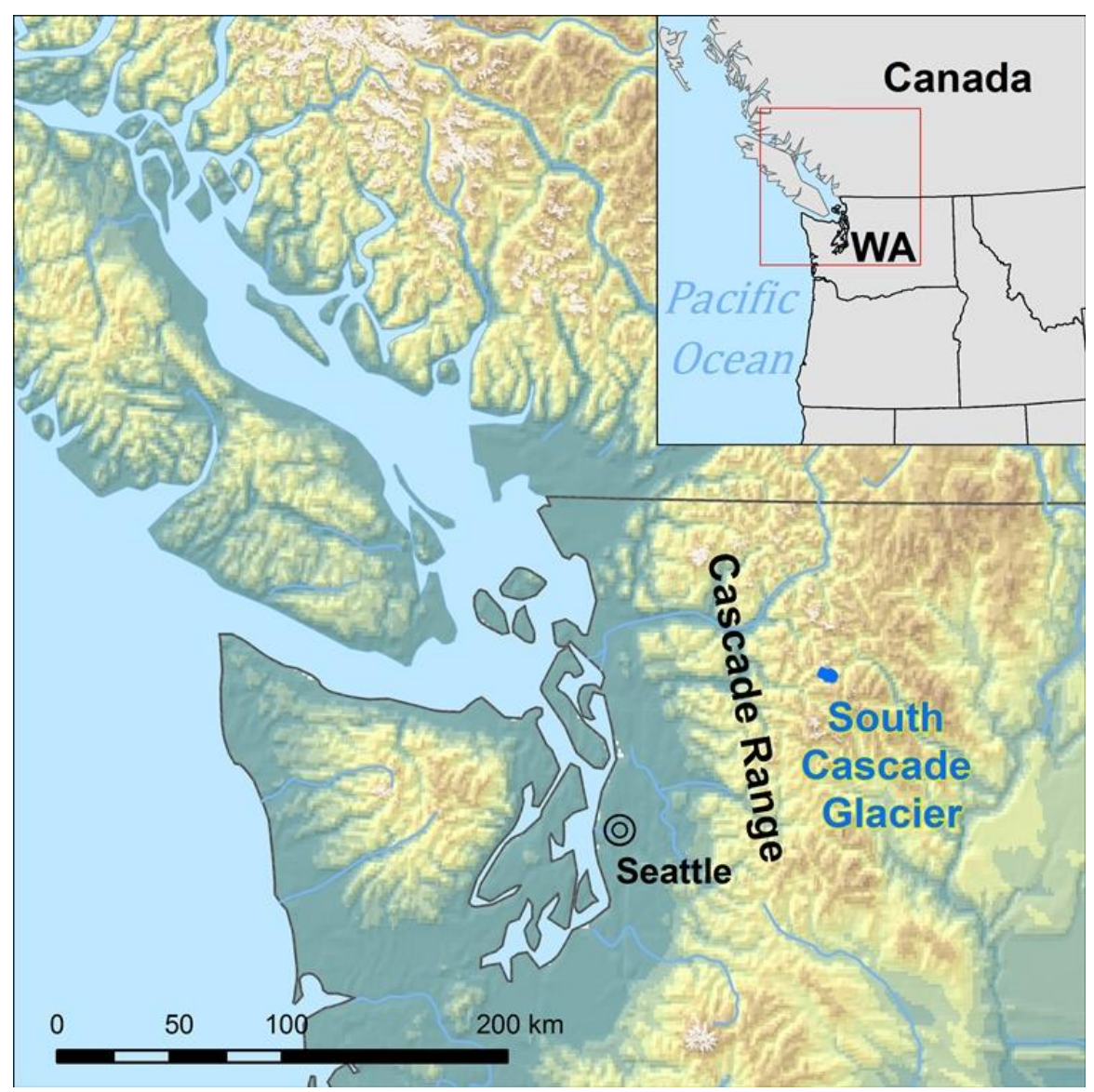

Figure 1. Map of northwestern Washington State showing the Cascade Range and location of South Cascade glacier (USGS, 2015). South Cascade Glacier is located at approximately $48.36^{\circ} \mathrm{N}, 121.06^{\circ} \mathrm{W}$ (Rasmussen and Conway, 2001).

\subsection{South Cascade Glacier}

South Cascade Glacier is a north-northwest facing valley glacier located along the crest of the North Cascades Range of northwestern Washington State (Meier and Tangborn, 1965; Bidlake et. al, 2010) (figure 1). In between Sentinel and Lizard Peaks, the glacier begins at an elevation of approximately 2,100 m (Meier and Tangborn, 1965) and flows downward in meandering character through the South Cascade Lake basin (Bidlake et. al, 2010) (figure 3). The glacier encounters several flat portions of the bed in between areas of steeper descent (Meier and Tangborn, 1965). Compared to most North Cascade glaciers, South Cascade Glacier exists at a lower altitude (Meier and Tangborn, 1965). South Cascade Lake basin is located between 1,613 $\mathrm{m}$ and 2, $518 \mathrm{~m}$ in elevation and surrounded by high 
relief mountain slopes (Bidlake et al., 2010). Melt water from South Cascade Glacier flows to the Cascade River's South Fork, one of the Skagit River's many tributaries (Bidlake et al., 2010).

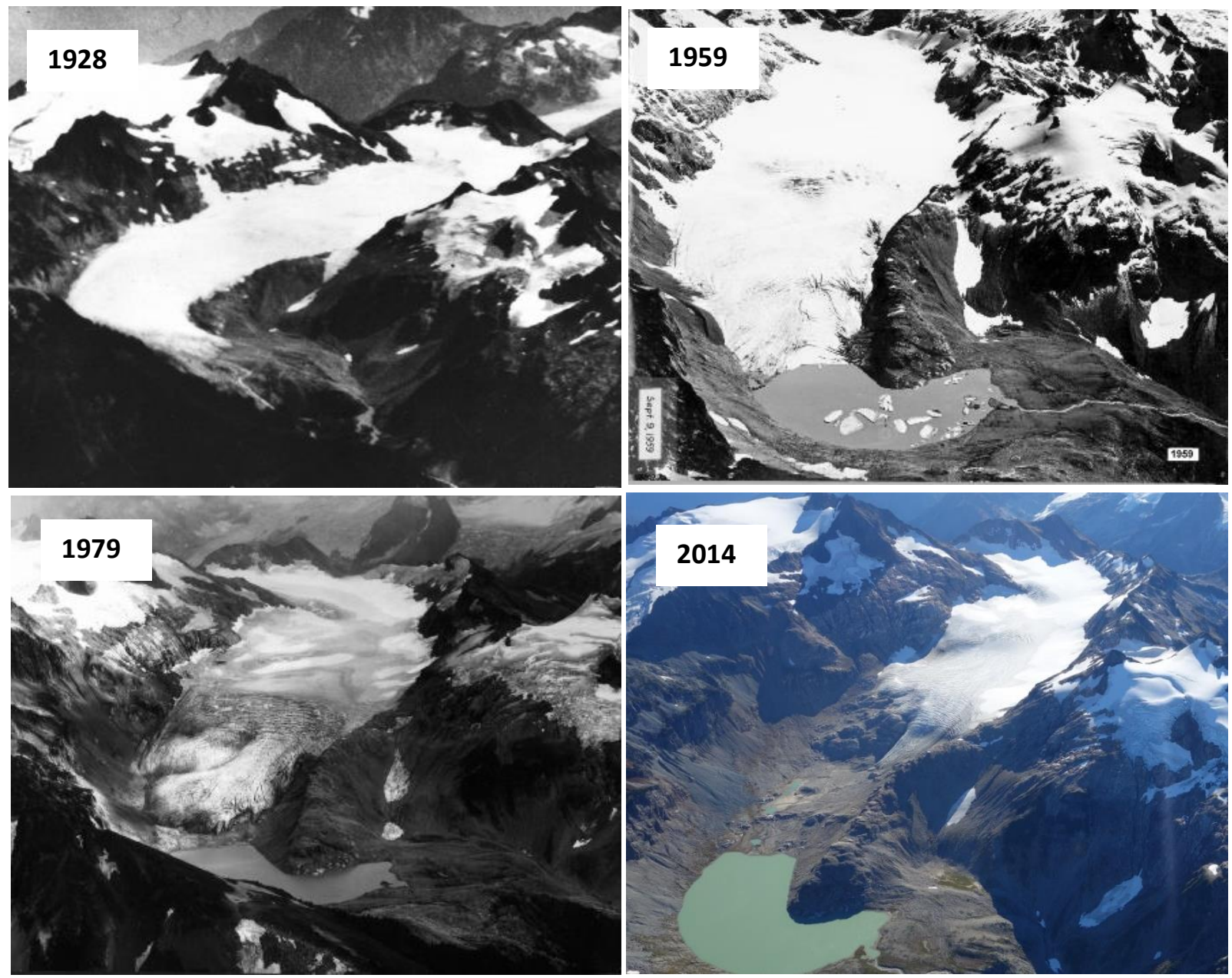

Figure 1. Historical aerial photography of South Cascade Glacier (USGS, 2015).

South Cascade Glacier reached its maximum extent at approximately 1600 (Meier et al., 1971).

Moraine dating gives evidence of other advances during the early Neoglacial as well as during the mid and late $19^{\text {th }}$ century (Miller, 1969; Meier et al., 1971). Since the late $19^{\text {th }}$ century, South Cascade Glacier has been continuously retreating (Tangborn, 1999). From 1958 to 2005 solely, the glacier receded $0.7 \mathrm{~km}$ and shrank from $2.71 \mathrm{~km}^{2}$ to $1.75 \mathrm{~km}^{2}$ (Bidlake et al., 2010). In total, the glacier receded approximately 
$1.6 \mathrm{~km}$ from its Little Ice Age position to its present-day position (Miller, 1969; Bidlake et al., 2010). South Cascade Glacier terminated in South Cascade Lake between 1928 and 1979 (figure 2).

The climate at South Cascade Glacier is maritime - winters are characteristically wet and mild and summers are cool and dry (Tangborn, 2000). Temperature extremes vary from $-10^{\circ} \mathrm{C}$ during winter and $20^{\circ} \mathrm{C}$ during summer (Bidlake et al. 2010). Snowfall on South Cascade Glacier occurs from October to May and maximum precipitation arises in April or May (Bidlake et al., 2010). Net mass balance for the glacier from 1953 to 2005 averaged $-0.57 \mathrm{~m}$ weq, where negative net balances outnumbered positive net balances by a factor of 2 (Bidlake et al., 2010). Between the years 1928 and 1944, net balance is estimated at $-1.7 \mathrm{~m}$ weq and between the years 1945 and 1965, the net balance is estimated to be $-0.6 \mathrm{~m}$ weq (Meier et al., 1971)). From 1958 to 1988 , the net balance averaged $-0.51 \mathrm{~m}$ weq, whereas the net balance averaged $-0.79 \mathrm{~m}$ weq from 1989 to 2005 (Bidlake et al., 2010). The equilibrium line altitude has been higher than the glacier episodically during recent times (for example, for 2003, 2004, 2005, and 2006) (Bidlake et al., 2010). The negative trend in net balance since the mid-1970s has been partially attributed to warmer winter temperatures and a reduction in winter balance (McCabe and Fountain, 1995).

South Cascade Glacier has been monitored for over five decades (Bidlake et al., 2010). The glacier is one of four "benchmark glaciers" - index glaciers of a certain glaciated region that are rigorously studied by the USGS to provide an understanding of climate and hydrological influences (Bidlake et al., 2010). In 1957, the USGS first began consistent measurements of South Cascade Glacier (Meier, 1958). For 1953 and between 1955 and 1957, aerial photographs were used to estimate balance (Bidlake et al., 2010). Between 1958 and 1964, Meier and Tangborn (1965) directly recorded glaciological measurements, such as ice velocity, surface elevation, and mass balance. Meier et al. (1971) reported on mass balance of South Cascade Glacier for 1965 to 1967. Krimmel (1989) summarized mass balances for years 1959 to 1985. Between 1986 and 2007, Krimmel (1993, 1994, 1995, 1996, 1997, 1998, 1999, 2000, 2001, and 2002) and Bidlake et al. (2004, 2005, 2007, and 2010) give detailed reports on glaciological, hydrological, and meteorological data of South Cascade Glacier. 
Other studies outside of the USGS have also been conducted on or around South Cascade Glacier. The chronology of neoglacial moraines of South Cascade Glacier was documented by Miller (1969). The mass balance of South Cascade Glacier was a focus for various modeling studies presented in Tangborn (1980), Tangborn (1999), Rasmussen and Conway (2001), and Rassmussen and Conway (2003). The energy balance of South Cascade Glacier was modeled by Anslow et al. (2008) to approximate the 2004 and 2005 summer mass balance. The relationship between atmospheric circulation and balance specific to South Cascade Glacier was investigated by McCabe and Fountain (1995). Also, the hydrology of South Cascade Glacier has been extensively studied by Fountain (1989, 1993, and 1994).

\subsection{Calving}

Calving has occurred at the terminus of South Cascade Glacier, as shown in figure 2. Calving is defined as "the mechanical loss of ice from glaciers and ice shelves" and is an important process of mass loss for many glaciers around the globe; however, it is still poorly understood (Benn et al., 2007b). Calving controls the retreat and advance of many glaciers. Calving glaciers are sensitive to climatic forcing, and may respond by fast retreat; however, it is unclear whether calving is caused by or induces this ice acceleration (Benn et al., 2007b). Calving is strongly dependent on ice thickness at the terminus and water depth, and these relationships have been mathematically defined by calving equations (Warren et al., 1995). Until recently, most research has been focused on tidewater calving, with minimal focus on freshwater calving (Warren et al., 1995). Freshwater calving glaciers are intermediate between noncalving and tidewater glaciers in the climate sensitivity spectrum, and freshwater calving rates may be as much as one order of magnitude less than tidewater calving rates (Benn et al., 2007b). In all, though, calving can have drastic impacts on a glacier as exemplified by the rapid retreat of Columbia Glacier of Alaska since 1982 (Walter et al., 2010) and of Glaciar Upsala of Patagonia since 1996. 


\section{Methodology}

\subsection{The Numerical Model: The Equations and Other Basics}

The basis for this research is a 2-dimensional flow line model that I adapted from the finiteelement thermomechanical flow line model developed by Parizek et al. (2005). The model uses the Galerkin method of weighted residuals as the finite-element modeling technique (Parizek et al., 2005). Hermite and linear polynomial functions permit the numerical stability of high order terms in the thermal and dynamic parts of the setup (Parizek et al., 2005). The model includes dimensions along the flow line of the glacier; in other words, the horizontal $(x)$ and vertical $(z)$ directions. The vertical dimension, or elevation, is described in relation to sea level and all variables (such as velocity) are resolved into their $x$ and $z$ components (Parizek et al., 2005). The model approximates the flow of ice using a form of Glen's Flow Law (Parizek et al., 2005)

$$
\varepsilon=A * \tau^{n}
$$

where $\varepsilon$ represents the strain rate, $A$ is related to ice viscosity, $n$ is designated as 3 , and $\tau$ represents shear stress. The quantity $A$ is dependent on temperature defined by equation 2 (Parizek et al., 2005).

$$
A(T)=a E * \exp \left(\frac{-Q}{R T^{*}}\right)
$$

where $T$ is temperature, $a$ is a rate constant, $E$ is an enhancement factor used for tuning purposes, $Q$ is the activation energy, $R$ is the universal gas constant, and $T^{*}$ is the ice temperature relative to the pressure melting point. Following that the basal resistance balances the gravitational driving stress resulting in power-law creep, the momentum balance is defined by equation 3 (Parizek et al., 2005):

$$
\tau_{z x}(z)=-\rho_{i} g(s-z) \frac{\partial s}{\partial x}
$$

where $\tau_{x z}$ is vertical shear stress, $\rho_{i}$ is ice density, $g$ is gravitational acceleration, $s$ is ice surface elevation, $z$ is the vertical position, and $x$ is the horizontal dimension along the flow line. Mass continuity is approximated by equation 4: 


$$
\frac{\partial h}{\partial t}=\frac{\partial}{\partial x}\left(D \frac{\partial s}{\partial x}\right)+\dot{A}-\dot{B}
$$

such that $h$ is ice thickness, $t$ is time, $x$ is distance along the flow line, $D$ is the effective diffusivity $\left(\left(D \frac{\partial s}{\partial x}\right)=-h \bar{u}\right.$, where $\bar{u}$ represents the vertically averaged horizontal velocity), $\dot{A}$ represents the surface accumulation rate (which takes on a positive sign for accumulation, negative sign for ablation), and $\dot{B}$ represents the basal melting rate (which takes on a positive sign when melt is occurring, and a negative sign when freezing is occurring). The horizontal ice velocity is derived using equation 5 , which results from equating Glen's Flow Law and the shear strain rate, defined by $\dot{\varepsilon}_{z x} \approx \frac{1}{2}\left(\frac{\partial s}{\partial z}\right)$, and vertically integrating.

$$
u(z)=u(b)-2 \rho_{i} g \frac{\partial s}{\partial x} I(z)
$$

where $z$ is the vertical dimension, $u(b)$ is the velocity at the ice base, $\rho_{i}$ is ice density, $g$ is gravitational acceleration, $s$ is ice surface elevation, $x$ is the horizontal dimension along the flow line, and $I(z)$ is the depth-dependent deformational velocity component (Parizek et al., 2005). To approximate the vertical ice velocity, the model implements equation 6 , which results from the combination of the definitions of $D$ and $I(z)$ :

$$
\begin{gathered}
\frac{\partial w}{\partial z}=-\frac{\partial u}{\partial x} \\
w(z)=w(b)-\int_{b}^{z} \frac{\partial u\left(z^{\prime}\right)}{\partial x} d z^{\prime}
\end{gathered}
$$

where $w$ is the vertical ice velocity, $z$ is the vertical dimension, $b$ is the ice base elevation, and $u$ is the horizontal ice velocity (Parizek et al., 2005). For a more detailed description of the model as well as its application to the Greenland Ice Sheet, see Parizek (2000) and Parizek et al., (2005). 


\subsection{Model Adaptations}

Since the numerical model generated by Parizek et al. (2005) is intended for use for an ice sheet, I enforced many alterations in order to design the model for application to South Cascade Glacier. The following paragraphs describe the characteristics specific to the South Cascade Glacier numerical model produced during this project.

\section{2a General Adaptions}

The current model has a grid spacing of $10 \mathrm{~m}$, a total grid length of $10 \mathrm{~km}$, and a total of 10001 nodes horizontally spaced along the flow line. The vertical mesh has a variable spacing and includes 15 nodes located from the base of the glacier to the ice surface. Because of the fine grid, I used a time step of $1 / 500$ yr to $1 / 700$ yr depending on the experiment.

Basal sliding is set to zero to approximate South Cascade Glacier conditions. The firn-layer dynamic portion of the model of Parizek et al. (2005) is not used in order to keep a simple mass balance. Additionally, the South Cascade Glacier model disregards the isostatic portion of Parizek et al. (2005) model in order to model valley glacier conditions. The temperature of South Cascade Glacier is set to be uniformly $0{ }^{\circ} \mathrm{C}$ throughout the glacier because it is a temperate glacier (Rasmussen and Conway, 2001); temperature glaciers, including their base, are typically at the melting point (Maohuan, 1990).

\section{2b Bed Elevation}

The bed topography from the head of South Cascade Glacier to the beginning of the lake basin is generated using the bed map shown in figure 3C. The flow line is taken through the deepest part of the bed, which approximately matches the flow line taken by Meier and Tangborn (1965). The bed begins by a steep descent at the head of the glacier, followed by two flatter stretches of the bed separated by sections of moderate descent (figure 3A). The lake basin begins at approximately $3.2 \mathrm{~km}$ along the flow line and is at most $80 m$ deep (Fountain, 2015). The lake basin begins at $1613 m$ in elevation and descends nearly 
linearly to an elevation of $1533 m$ (figure 3A). Past the lake basin, the bed descends more steeply (figure $3 \mathrm{~A})$.
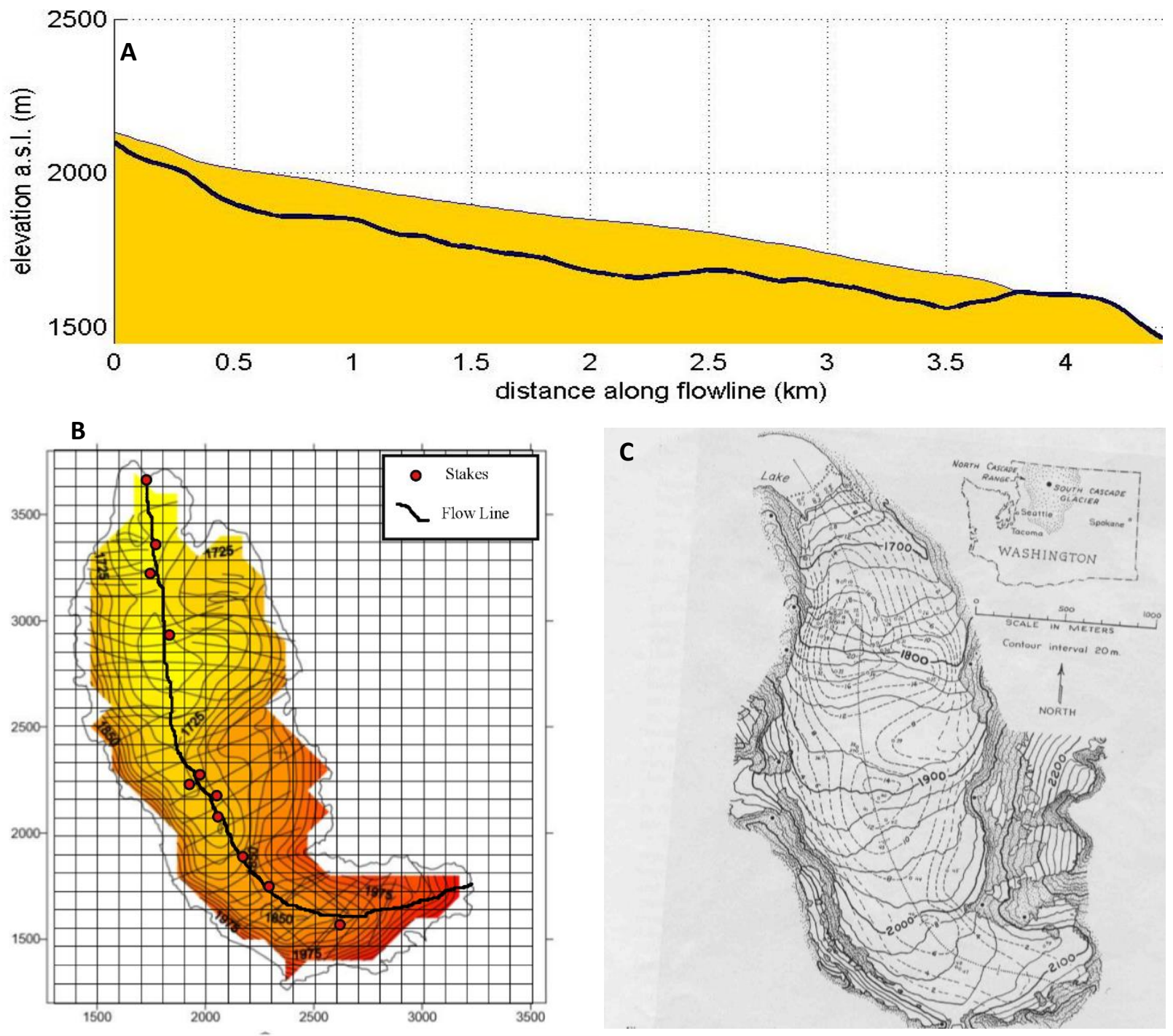

Figure 2. The bed topography of South Cascade Glacier. A) Shows the modeled bed elevation of South Cascade Glacier. B) Shows the model's flow line in relation to stake locations of Meier and Tangborn (1965). C) Shows the flow line of Meier and Tangborn (1965).

\section{2c Shape Factor}

The valley sides adjacent to a valley glacier provide resistance to ice flow (Hooke, 2005). The knowledge of how much drag is provided by the ice-bed interface is difficult to quantify, especially if the 
valley shape is unknown. A parameter that is especially helpful in modeling the ice-bed resistance to flow is known as the shape factor, defined by equation 7 (Hooke, 2005):

$$
S_{f}=A / P H
$$

where $S_{f}$ is the shape factor, $A$ represents the cross sectional area, $P$ represents the length of the ice-bed interface, and $H$ is the thickness of the glacier at the center line. For an infinitely wide glacier, the shape factor is equal to 1 . For a semicircular valley, the shape factor is equal to $1 / 2$. For the purpose of this project, the shape factor is set to $1 / 2$.

\section{2d Mass Balance}

Variations in the net mass balance of South Cascade Glacier can be substantial, however the shape of the curve of the net mass balance with altitude remains generally consistent (figure 4). Because of this, the net mass balance can be modeled by approximating the curve and changing its relative position according to the equilibrium line altitude for the correlative year.

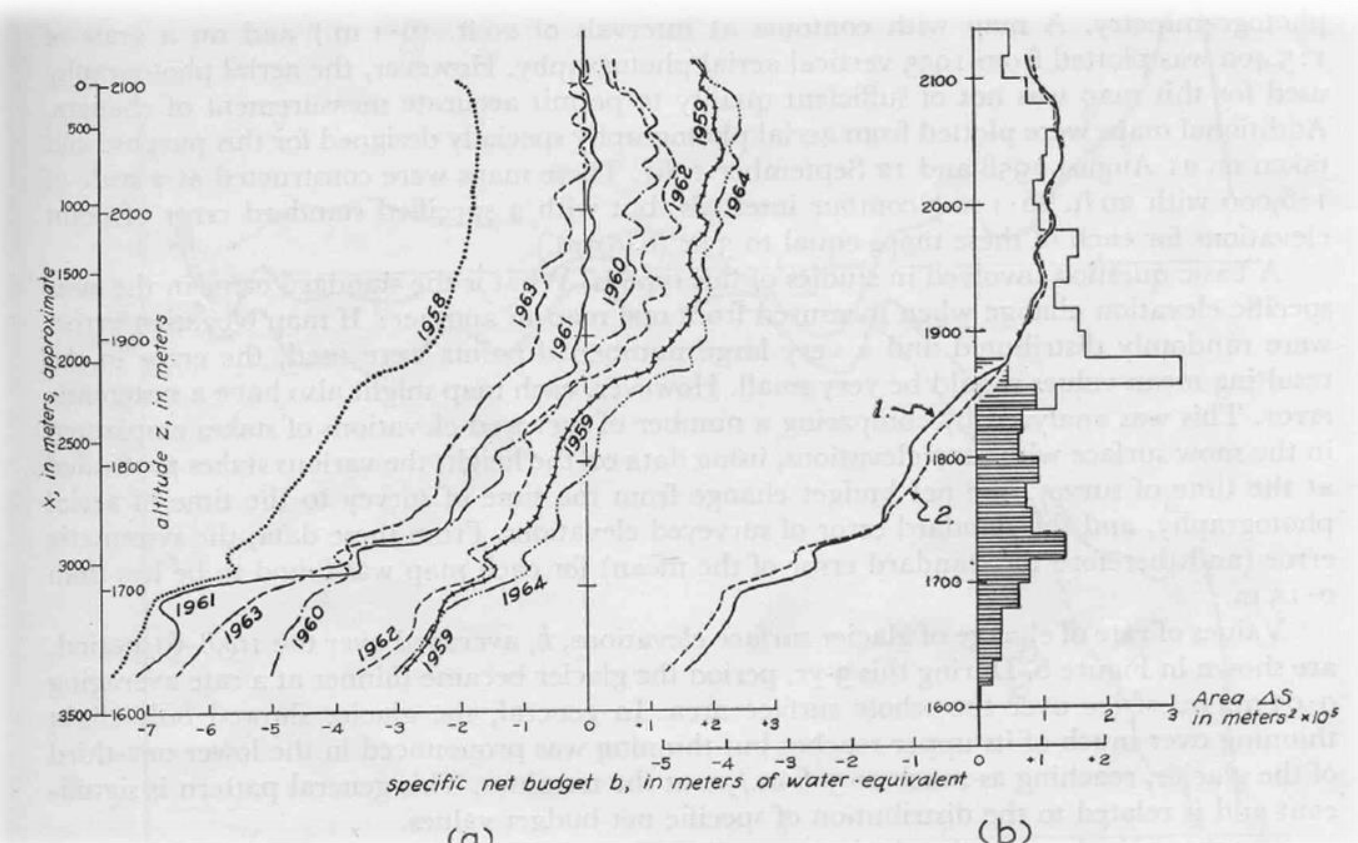

Figure 3. a) Net balance with altitude b(z) curves from 1958 - 1964 for South Cascade Glacier. b) Curve 1 shows the averaged net balance with altitude curve for years 1957 to 1964, where increments of altitude are taken to be $10 \mathrm{~m}$. Curve 2 represents b(z) for 1961 (Meier and Tangborn, 1965). 
A Lagrange interpolating polynomial of $10^{\text {th }}$ degree is used to generate the net mass balance with altitude curve (equation 8) using eleven total data points that were inferred from curve 1 of figure 4 of Meier and Tangborn (1965). Note that $f(z)$ is the net mass balance as a function of altitude and $z_{i}$ is the altitude at the $i^{\text {th }}$ node or data point. Seven of the points were directly measured from curve 1 and four of the points were determined by extrapolation at or below $1600 \mathrm{~m}$ in altitude.

$$
\begin{aligned}
P_{10}(x)= & f\left(z_{0}\right) * \frac{\left(z-z_{1}\right)\left(z-z_{2}\right)\left(z-z_{3}\right)\left(z-z_{4}\right)\left(z-z_{5}\right) \ldots\left(z-z_{9}\right)}{\left(z_{0}-z_{1}\right)\left(z_{0}-z_{2}\right)\left(z_{0}-z_{3}\right)\left(z_{0}-z_{4}\right)\left(z_{0}-z_{5}\right) \ldots\left(z_{0}-z\right)} \\
& +f\left(z_{1}\right) * \frac{\left(z-z_{0}\right)\left(z-z_{2}\right)\left(z-z_{3}\right)\left(z-z_{4}\right)\left(z-z_{5}\right) \ldots\left(z-z_{9}\right)}{\left(z_{1}-z_{0}\right)\left(z_{1}-z_{2}\right)\left(z_{1}-z_{3}\right)\left(z_{1}-z_{4}\right)\left(z_{1}-z_{5}\right) \ldots\left(z_{1}-z\right)} \\
& +\ldots f\left(z_{11}\right) * \frac{\left(z-z_{0}\right)\left(z-z_{2}\right)\left(z-z_{3}\right)\left(z-z_{4}\right)\left(z-z_{5}\right) \ldots\left(z-z_{9}\right)}{\left(z_{11}-z_{0}\right)\left(z_{11}-z_{2}\right)\left(z_{11}-z_{3}\right)\left(z_{11}-z_{4}\right)\left(z_{11}-z_{5}\right) \ldots\left(z_{11}-z\right)}
\end{aligned}
$$

The resulting curve $f(z)(5)$ closely resembles curve 1 of Meier and Tangborn (1965). Notice the nearly linear nature of the function until about $1900 \mathrm{~m}$ in altitude, where the net mass balance begins a slower increase with elevation. At $2000 \mathrm{~m}$ in altitude, the curve flattens out vertically. Finally, the net mass balance decreases slightly with altitude at about $2025 \mathrm{~m}$ in altitude.

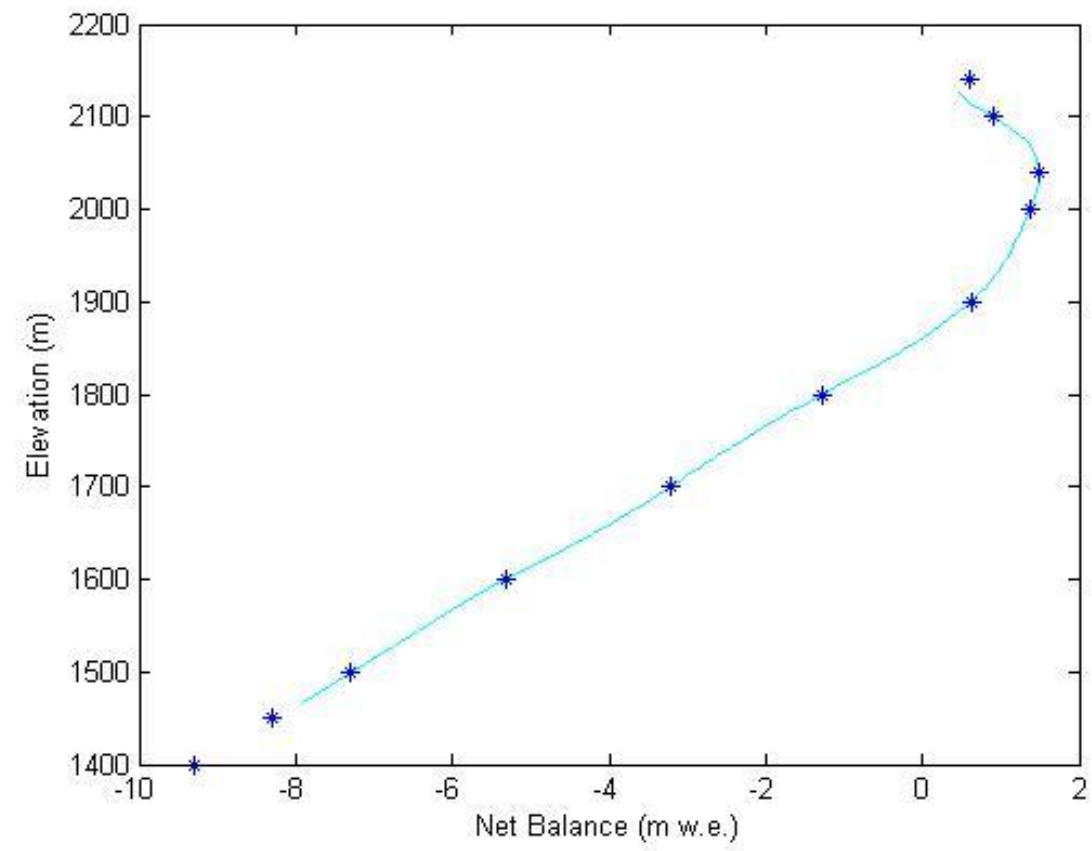

Figure 4. Net mass balance curve with elevation $(f(z))$ for South Cascade Glacier modeled by using a $10^{\text {th }}$ degree Lagrange Interpolating Function. Blue asterisks represent the data points inferred from curve 1 of Meier and Tangborn (1965). 
To model the mass balance from 1890 to 2007 , the balance curve from 5 is used. The average annual equilibrium line altitude designates the mean altitude where the net balance is zero during a balance year. The equilibrium line altitude annually fluctuates for South Cascade Glacier, as shown in figure 6. To account for this, the model takes the ELAs for each year and sets the balance with altitude function $(f(z))$ at 0 :

$$
f(\text { Equililbrium Line Altitude })=0
$$

The model uses annual equilibrium line altitudes from Bidlake et al. (2004, 2005, 2007, 2010) for years 2002 to 2007 and from Krimmel et al. $(1993,1994,1995,1996,1997,1998,1999,2001,2002)$ for 1992 to 2000. Equilibrium line altitudes for 1931 to 1992 were obtained from Tangborn (1999), who reconstructed the mass balance of South Cascade Glacier from 1932 to 1996. There are no measured or modeled ELAs for 1890 to 1931 for South Cascade Glacier. Because we approximately know the glacier's length at intervals during and shortly after this time period, we experimented with different ELAs for 1890 to 1931 necessary to produce the known lengths. The results showed that an average ELA of $2015 m$ was necessary for this time period.

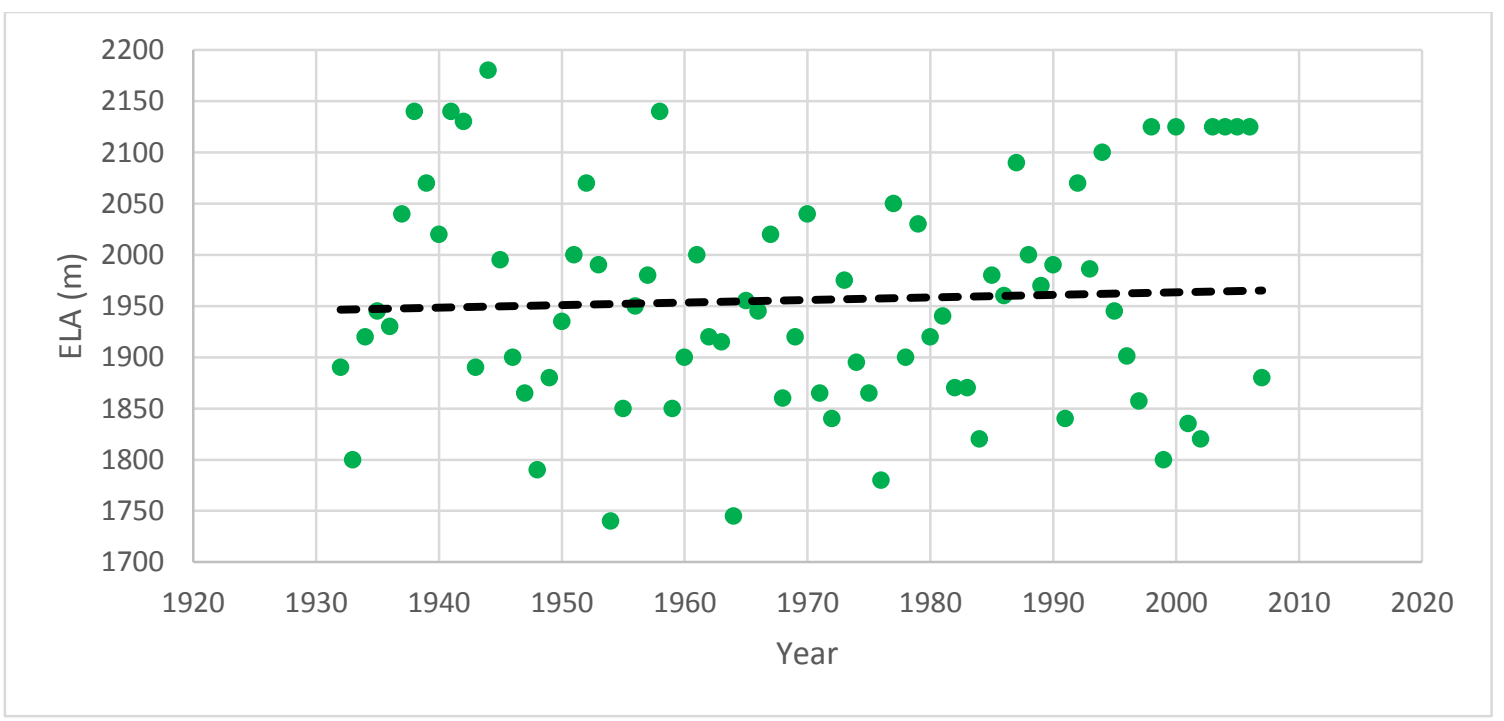

Figure 5. Equilibrium line altitudes for South Cascade Glacier from 1932 to 2007. ELAs from 1932 to 1992 were obtained from Tangborn (1999) and ELAs from 1992 were obtained from Krimmel (1993, 1994, 1995, 1996, 1997, 1998, 1999, 2001, 2002). ELAs from 1890 to 1931 we determined from experiments. 


\section{2e Calving}

Most calving studies have discovered that calving shows a strong linear dependence on the water depth at the terminus of a glacier (Benn et al., 2007b). Following the observation that tidewater and freshwater terminating glaciers show different calving sensitivities (Benn et al, 2007b), I use an exclusively freshwater calving equation (equation 10) to approximate calving of South Cascade Glacier (Warren and Kirkbride, 2003). Warren and Kirkbride (2003) sampled twenty one New Zealand freshwater calving glaciers and derived equation 10, which shows that the calving rate $\left(U_{C}\right)$ is linearly related to the water depth at the terminus $\left(D_{W}\right)$.

$$
U_{C}=17.4+2.3 D_{W}\left(m a^{-1}\right)
$$

Some studies have shown that the dependence of the calving rate on water depth may not be as straightforward as the linear dependence shown in many calving equations (such as equation 10), and that the calving rate may vary between regions or may vary with time for a single glacier (Benn et al., 2007b). Calving may depend strongly on dynamic controls such as subglacial water flux, instead of outside environmental ones (Benn et al., 2007b), which equation 10 obviously does not account for. Despite this, the calving equation provides a direct, albeit simple, relationship using data that is accessible for South Cascade Glacier and is sufficient for this project.

\section{Experiments with the Numerical Model}

\subsection{Accuracy of the Model}

Since the numerical model is the basis if this project, its accuracy is highly integral in producing a reasonable outcome for this project. An obvious test for accuracy is to compare the model's velocity results with the calculated velocity results of the analytic solution (equation 11) in several simple experiments.

$$
u(z)=\frac{A}{2}\left(\rho_{i} * g * \tan (a)\right)^{3} z^{4}
$$


where $u(z)$ is the velocity, $A$ represents the constant of Glen's flow law, $\rho_{i}$ is the density of ice, $g$ represents gravitation acceleration, $a$ is the slope in degrees, and $z$ is the position in the ice column. Note that this equation is applicable for a glacier of infinite length, which is not possible to create in this model. The modeled velocity of a $2.8 \mathrm{~km}$ glacier on a flat bed and 8 degree slope (figure 7 ), a $4 \mathrm{~km}$ glacier on a flat bed and 12 degree slope, and a $30 \mathrm{~km}$ glacier on a 0.1 degree slope and are compared with the respective velocities determined by equation 11 .

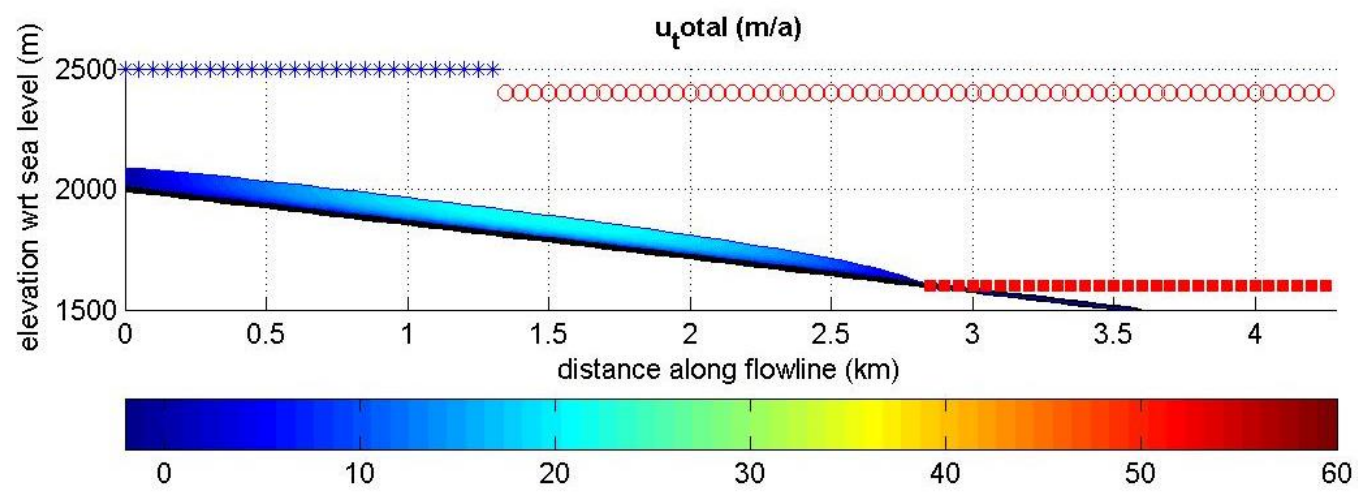

Figure 6.A modeled glacier of $2.8 \mathrm{~km}$ on a flat bed and an 8 degree slope - one of the profiles used to test the model's accuracy.

A comparison of the results are shown in table 1,2, and 3. The experiments here show that the approximation to the analytic solution improves with a longer glacier and improves with distance towards the center of the glacier. 
Table 1. Results of the $2.5 \mathrm{~km}$ glacier on a flat bed and an 8 degree slope. This experiment shows that the glacier is too short for a sound comparison between the analytic solution and the model velocities.

\begin{tabular}{ccccc}
\hline $\begin{array}{c}\text { Distance along } \\
\text { Flowline }(\mathbf{k m})\end{array}$ & Ice Thickness $(\boldsymbol{m})$ & $\begin{array}{c}\text { Numerical } \\
\text { Solution } \\
\left(\boldsymbol{m} \boldsymbol{y} \boldsymbol{r}^{-\mathbf{1}}\right)\end{array}$ & $\begin{array}{c}\text { Analytic } \\
\text { Solution } \\
\left(\boldsymbol{m} \boldsymbol{y} \boldsymbol{r}^{-1}\right)\end{array}$ & \% Difference \\
\hline 0.5 & 103.58 & 12.33 & 16.27 & $24.22 \%$ \\
1.0 & 106.29 & 19.12 & 18.04 & $5.99 \%$ \\
1.5 & 102.39 & 21.38 & 15.53 & 38.16 \\
2.0 & 90.77 & 18.91 & 9.59 & $97.18 \%$ \\
\hline
\end{tabular}

Table 2. Results for a $4 \mathrm{~km}$ glacier on a flat bed and 12 degree slope for analysis of the model's accuracy.

\begin{tabular}{lllll}
\hline $\begin{array}{c}\text { Distance along } \\
\text { Flowline }(\boldsymbol{k m})\end{array}$ & \multicolumn{1}{c}{$\begin{array}{c}\text { Ice Thickness } \\
(\boldsymbol{m})\end{array}$} & $\begin{array}{c}\text { Numerical Solution } \\
\left(\boldsymbol{m} \boldsymbol{y} \boldsymbol{r}^{-\mathbf{1}}\right)\end{array}$ & $\begin{array}{c}\text { Analytic Solution } \\
\left(\boldsymbol{m} \boldsymbol{y r}^{-\mathbf{1}}\right)\end{array}$ & $\begin{array}{c}\text { \% } \\
\text { Difference }\end{array}$ \\
\hline 0.5 & 96.38 & 31.18 & 42.18 & $26.09 \%$ \\
1.0 & 103.83 & 50.64 & 56.82 & $10.88 \%$ \\
1.5 & 106.94 & 62.66 & 63.94 & $2.00 \%$ \\
2.0 & 107.23 & 68.17 & 62.74 & $8.65 \%$ \\
2.5 & 104.85 & 67.42 & 59.08 & $14.12 \%$ \\
3.0 & 99.04 & 60.18 & 47.04 & $27.93 \%$ \\
3.5 & 86.78 & 45.64 & 27.73 & $64.59 \%$ \\
\hline
\end{tabular}

Table 3. Results for a $30 \mathrm{~km}$ glacier on a flat bed and 0.01 degree slope for analysis of the model's accuracy.

\begin{tabular}{cccc}
\hline $\begin{array}{c}\text { Distance Along Flow } \\
\text { Line }(\boldsymbol{k m})\end{array}$ & $\begin{array}{c}\text { Numerical Solution } \\
\left(\boldsymbol{m} \boldsymbol{y r}^{-\mathbf{1}}\right)\end{array}$ & $\begin{array}{c}\text { Analytic Solution } \\
\left(\boldsymbol{m} \boldsymbol{y} \boldsymbol{r}^{-\mathbf{1}}\right)\end{array}$ & \% Difference \\
\hline 19 & 0.0022 & 0.0022 & $0.00 \%$ \\
20 & 0.0023 & 0.0022 & $4.50 \%$ \\
20.5 & 0.0023 & 0.0022 & $4.50 \%$ \\
\hline
\end{tabular}


For the $4 \mathrm{~km}$ long glacier, velocities closer to the center of the glacier are closest to the analytic solution, as seen in Table 2, and become increasingly inaccurate with distance from the center. The $4 \mathrm{~km}$ glacier achieves more accuracy to the analytic solution than the $2.8 \mathrm{~km}$ glacier. This is not surprising, since the analytic solution pertains to an infinitely long glacier. With increasing proximity to the boundaries (i.e. the head and terminus of the glacier), the analytic solution fails to account for the physics that occurs there. For example, the head experiences no positive horizontal flux of mass from upglacier, and the terminus experiences less resistance to flow because of the lack of ice on the terminal side. However, the model does approximate the analytic solution with as little as a $2 \%$ difference in the central region of the glacier. Also, the central region of the $30 \mathrm{~km}$ glacier consistently has a $4.5 \%$ difference to the analytic solution for $1.5 \mathrm{~km}$. Because the glacier approximates the analytic solution closely in these sections, we can firmly conclude that the model's accuracy is sufficient for this project.

\subsection{Model Calibration}

We conduct several experiments in order to calibrate the model. A comparison of a model with $10 m$ nodal spacing is compared with a model with $50 m$ nodal spacing by a simulation of South Cascade Glacier starting in an equilibrium state from 1940 to 1964 . The results obtained illustrate the limitations of a large nodal spacing, especially when modeling on a finer scale. Table 4 shows the horizontal velocity results using a $10 \mathrm{~m}$ and $50 \mathrm{~m}$ nodal spacing for simulating 1940 to 1964 . We observe that the model with $10 \mathrm{~m}$ nodal spacing yields a glacier with length of $3.66 \mathrm{~km}$, whereas the $50 \mathrm{~m}$ nodal spacing produces a $3.64 \mathrm{~km}$ glacier. The difference in length can be understood by realizing that the $10 \mathrm{~m}$ nodal spacing allows the glacier to terminate at a position that may be closer to the climatically driven profile than the $50 \mathrm{~m}$ nodal spacing. The $50 \mathrm{~m}$ nodal spacing forces the glacier to terminate at positions that are $50 \mathrm{~m}$ apart. For example, if the glacier is responding to rising ELAs by retreat (because it is attempting to come to equilibrium with the new ELAs), the glacier has to accumulate enough "retreat" to recede by $50 \mathrm{~m}$, even if a position $10 \mathrm{~m}$ back may be more desirable in the interim. The velocity results from the $10 \mathrm{~m}$ nodal spacing simulation are generally lower and more comparable to velocities of Meier and Tangborn 
(1965) than those from the $50 \mathrm{~m}$ (Table 4). A disadvantage of using a $10 \mathrm{~m}$ nodal spacing compared with a $50 \mathrm{~m}$ nodal spacing is that the model takes longer to run because we have to reduce the time step $(1 / 500$ yr vs. 1/60 yr, respectively). However, the $10 \mathrm{~m}$ nodal spacing diminishes the errors related to model setup (i.e. more calculations because of more nodes will be more accurate), and is chosen for the rest of the experiments.

Table 4. End results for the 1940-1964 simulation using both 10 meter and 50 meter nodal spacing.

\begin{tabular}{cccc}
\hline $\begin{array}{c}\text { x }(\mathrm{m}) \begin{array}{c}\text { along the center } \\
\text { flowline }\end{array} \\
632\end{array}$ & $\begin{array}{c}\text { Real Velocity } \\
(\mathrm{m} / \mathrm{a})\end{array}$ & $\begin{array}{c}\text { Velocity } 50 \mathrm{~m} \text { nodal } \\
\text { spacing (m/a) }\end{array}$ & $\begin{array}{c}\text { Velocity 10m nodal } \\
\text { spacing (m/a) }\end{array}$ \\
\hline 1044 & 4.6 & 7.9 & 7.9 \\
1234 & 7.4 & 15.05 & 16.3 \\
1471 & 7.8 & 17.05 & 15.7 \\
1591 & 11.0 & 17.03 & 16.6 \\
1664 & 11.9 & 17.35 & 17.0 \\
1719 & 12.2 & 17.49 & 17.1 \\
2438 & 15.1 & 17.43 & 17.5 \\
2746 & 17.5 & 17.1 & 17.6 \\
2710 & 19.1 & 16.98 & 15.4 \\
2960 & 17.9 & 16.82 & 16.5 \\
3261 & 15.7 & 14.33 & 14.7 \\
& 11.0 & 6.76 & 6.0 \\
\hline
\end{tabular}

As stated previously, the measurements obtained by Meier and Tangborn (1965) provide a basis for checking the model results against. The model's ice surface elevation at 1960 after a spin-up of 20 years is compared with ice surface elevation measurements made by Meier and Tangborn (1965) of South Cascade Glacier (table 5). Since the bed topography of the model is assumed to be consistent with that of Meier and Tangborn (1965), the discrepancies in surface elevation are a result of differences in ice thickness. Overall, the model calculates a thinner glacier compared with the field measurements. The discrepancy in ice thickness is particularly pronounced towards the head of the glacier with a relative decrease downglacier. 
Table 5. Comparison of surface elevation from Meier and Tangborn (1965) and the model's surface elevation for South Cascade Glacier circa 1960.

\begin{tabular}{cccc}
\hline $\begin{array}{c}\text { X along flow line } \\
(\mathrm{m})\end{array}$ & $\begin{array}{c}\text { Meier and Tangborn }(1965) \text { Surface } \\
\text { Elevation }(\mathrm{m})\end{array}$ & $\begin{array}{c}\text { Model Surface Elevation } \\
(\mathrm{m})\end{array}$ & $\begin{array}{c}\text { Elevation Difference } \\
(\mathrm{m})\end{array}$ \\
\hline 0.8 & 2043 & 1970 & 73 \\
0.8 & 2049 & 1970 & 79 \\
1.2 & 2002 & 1917 & 85 \\
1.4 & 1966 & 1894 & 72 \\
1.6 & 1945 & 1873 & 72 \\
1.7 & 1936 & 1862 & 74 \\
1.9 & 1910 & 1842 & 68 \\
2.2 & 1879 & 1819 & 60 \\
2.2 & 1879 & 1819 & 60 \\
2.6 & 1842 & 1776 & 66 \\
2.7 & 1777 & 1760 & 17 \\
2.8 & 1792 & 1746 & 46 \\
3 & 1735 & 1708 & 27 \\
3.2 & 1675 & 1654 & 21 \\
\hline
\end{tabular}

In order to gain some insight into the cause of these ice thickness discrepancies, a second set of experiments from 1940 to 1964 is performed beginning from an equilibrium state. Because Meier and Tangborn (1965) measurements suggest a thicker glacier, a natural question to ask is whether the model is accurately approximating the ice flow of South Cascade Glacier; that is, are the components of the flow law used in the model producing a good approximation. Since direct measurements of these flow parameters are not known for South Cascade Glacier, we are left with making educated guesses at their values. We compare the results of an experiment that implements a reduced viscosity-related flow parameter $A\left(24 * 10^{-25} s^{-1} \mathrm{~Pa}^{-3}\right)$ with those that use the original $A\left(48 * 10^{-25} \mathrm{~s}^{-1} \mathrm{~Pa}^{-3}\right)$ (figure 8). Both simulations started at an equilibrium state. In relation with the original $A$ value, the model overall produces over twice as high velocities for the same glacier length (table 6), yields a thicker glacier with the lower $A$ value (table 7), and yields a glaciers that responds more slowly to the variations in climate (figure 8). 

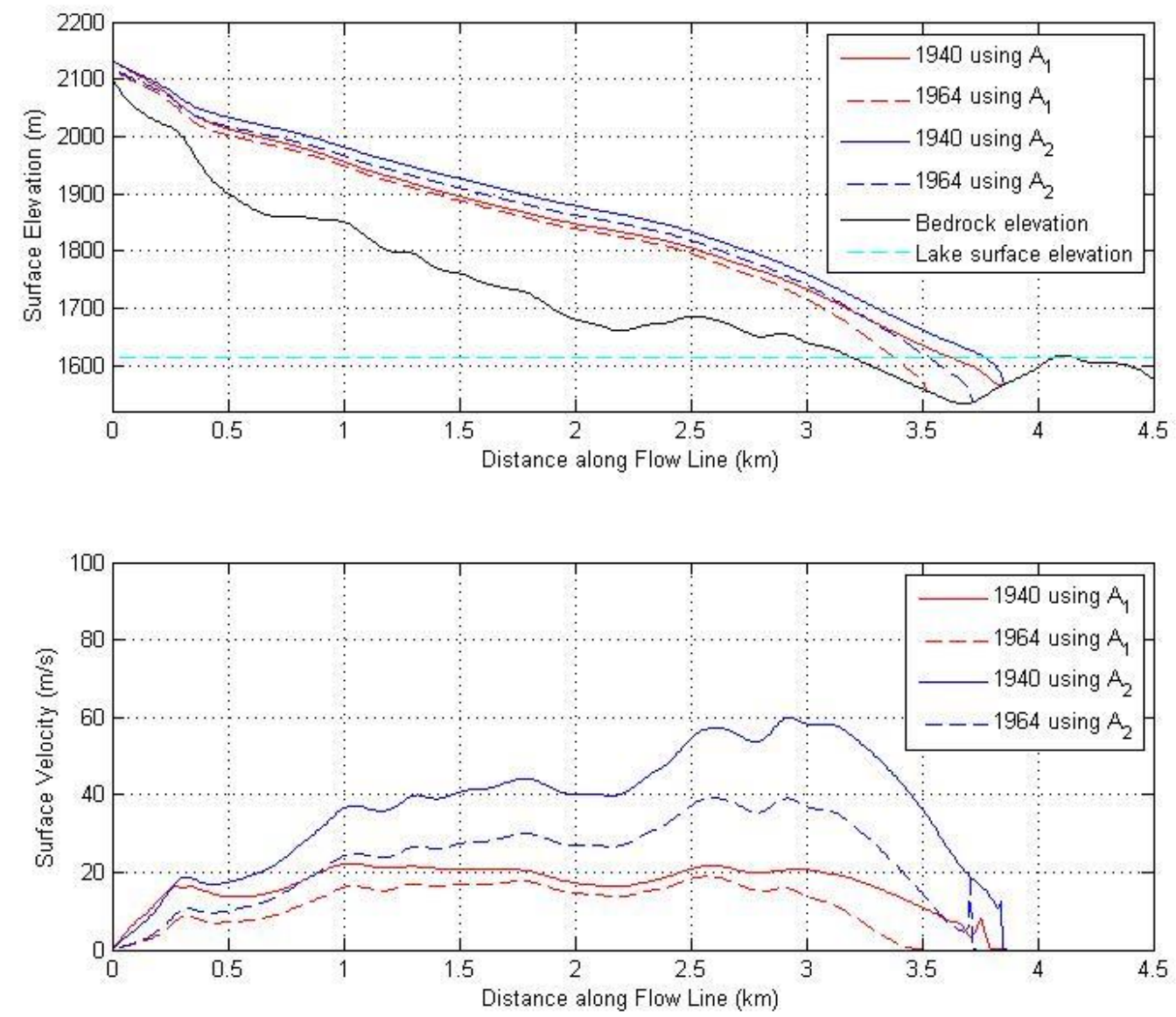

Figure 8. Ice thickness and velocity profiles of the initial and final profiles of the 1940 to 1964 simulation using with $A_{1}=48 * 10^{-25} \mathrm{~s}^{-1} \mathrm{~Pa}^{-3}$ and $A_{2}=24 * 10^{-25} \mathrm{~s}^{-1} \mathrm{~Pa}^{-3}$.

The model glacier with $A=24 * 10^{-25} \mathrm{~S}^{-1} \mathrm{~Pa}^{-3}$ is thicker than the model glacier with $A=48 *$ $10^{-25} \mathrm{~s}^{-1} \mathrm{~Pa}^{-3}$, but still remains much thinner than the measurements of Meier and Tangborn (1965), particularly near the head (figure 8 and Table ). This experiment also shows that adjusting the ice to be more viscous has caused the model glacier to respond slower to the variations in climate. The glacier with reduced $A$ retreated to only $3.72 \mathrm{~km}$ by 1964 compared to $3.5 \mathrm{~km}$ for the original glacier and $3.42 \mathrm{~km}$ for the measured glacier length (Meier and Tangborn, 1965). Therefore, the setup with $A=24 *$ $10^{-25} \mathrm{~S}^{-1} \mathrm{~Pa}^{-3}$ does not model the dynamic response of South Cascade Glacier. 
Table 6. Comparison of surface velocities for the 1964 profile with $A_{1}=48 * 10^{-25} \mathrm{~s}^{-1} \mathrm{~Pa}^{-3}$ and $A_{2}=$ $24 * 10^{-25} \mathrm{~S}^{-1} \mathrm{~Pa}^{-3}$ after simulating 24 years. Distances along the flow line are chosen based on stake locations from Meier and Tangborn (1965).

\begin{tabular}{cccc}
\hline $\begin{array}{c}\mathrm{x} \text { along flow } \\
\text { line }(\mathrm{km})\end{array}$ & $\begin{array}{c}\text { Meier and Tangborn }(1965) \\
\text { Surface Velocity }(\mathrm{m} / \mathrm{a})\end{array}$ & $\begin{array}{c}\text { Surface velocity for A_1 } \\
(\mathrm{m} / \mathrm{a})\end{array}$ & $\begin{array}{c}\text { Surface velocity for A_2 } \\
(\mathrm{m} / \mathrm{a})\end{array}$ \\
\hline 0.8 & 4.7 & 9.1 & 16.8 \\
1.2 & 7.4 & 13 & 24 \\
1.4 & 7.8 & 14 & 26.1 \\
1.6 & 11 & 14.6 & 27.9 \\
1.7 & 11.3 & 14.9 & 29.1 \\
1.9 & 15.1 & 13.9 & 28.1 \\
2.2 & 11.2 & 11.8 & 26.9 \\
2.6 & 17.6 & 15.4 & 39.2 \\
2.7 & 14.2 & 13.9 & 37.5 \\
2.8 & 15.7 & 11.8 & 35.4 \\
3 & 15 & 10 & 26.8 \\
3.2 & 11 & 4.4 & 29.7 \\
3.5 & 12 & 0 & 14.6 \\
\hline
\end{tabular}

Table 7. Comparison of surface elevations for the 1964 profile with $A_{1}=48 * 10^{-25} \mathrm{~s}^{-1} \mathrm{~Pa}^{-3}$ and $A_{2}=$ $24 * 10^{-25} \mathrm{~s}^{-1} \mathrm{~Pa}^{-3}$ after simulating 24 years. Distances along the flow line are chosen based on stake locations from Meier and Tangborn (1965).

\begin{tabular}{cccc}
\hline $\begin{array}{c}\text { x along flow line } \\
(\mathrm{km})\end{array}$ & $\begin{array}{c}\text { Meier and Tangborn }(1965) \text { Surface } \\
\text { Elevation }(\mathrm{m})\end{array}$ & $\begin{array}{c}\text { Surface Elevation for A_1 } \\
(\mathrm{m})\end{array}$ & $\begin{array}{c}\text { Surface Elevation for } \\
\text { A_2 }(\mathrm{m})\end{array}$ \\
\hline 0.8 & 2043 & 1970 & 1990 \\
1.2 & 2002 & 1917 & 1942 \\
1.4 & 1966 & 1894 & 1920 \\
1.6 & 1945 & 1873 & 1900 \\
1.7 & 1936 & 1862 & 1890 \\
1.9 & 1910 & 1842 & 1871 \\
2.2 & 1879 & 1819 & 1848 \\
2.6 & 1842 & 1776 & 1804 \\
2.7 & 1777 & 1760 & 1789 \\
2.8 & 1792 & 1746 & 1775 \\
3 & 1735 & 1708 & 1740 \\
3.2 & 1675 & 1654 & 1696 \\
\hline
\end{tabular}

Since reducing the flow parameter $A$ by half did not help the model fit, $A=48 * 10^{-25} s^{-1} \mathrm{~Pa}^{-3}$ is used for subsequent experiments, and we come to the conclusion that there must be other factors that can account for the inconsistencies in ice thickness. Firstly, the flow of South Cascade Glacier is characterized by a pronounced bend towards the head of the glacier. This may act as a "traffic jam" and 
cause the ice upglacier to accumulate slightly more than if there were no bend. Because the numerical model is 2-dimensional, it does not account for this irregularity in the flow line. Secondly, the model does not account for mass flowing in from the sides or out towards the margins. The accumulation zone is characterized by mass flowing into the central region from the margins, whereas in the ablation zone mass in general flows outward. Again, the 2-dimensional nature of the model may provide a limitation on the accuracy of the results.

\subsection{Sensitivity of the model}

The modeled glacier shows great sensitivity to changes in mass balance and bed topography. For example, only minor changes in the bed topography cause the glacier for a set mass balance to change greatly in length and ice velocity (figure 8).
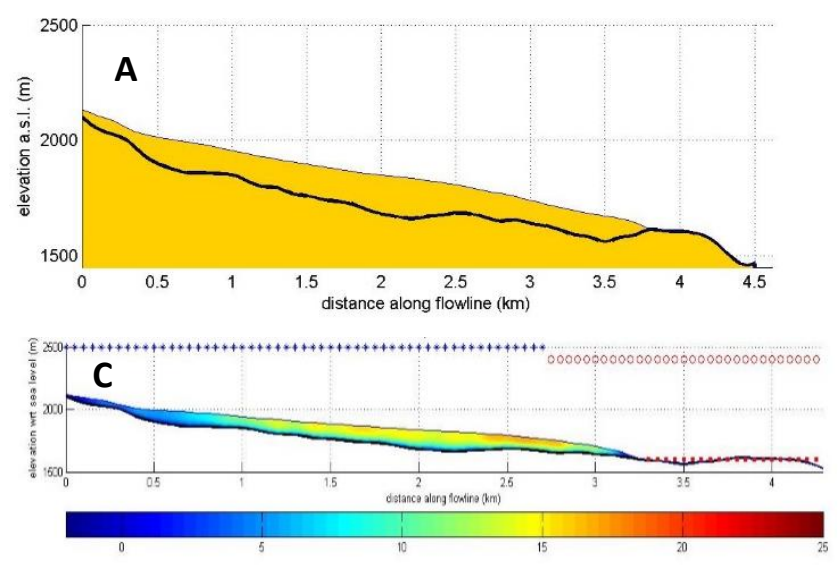
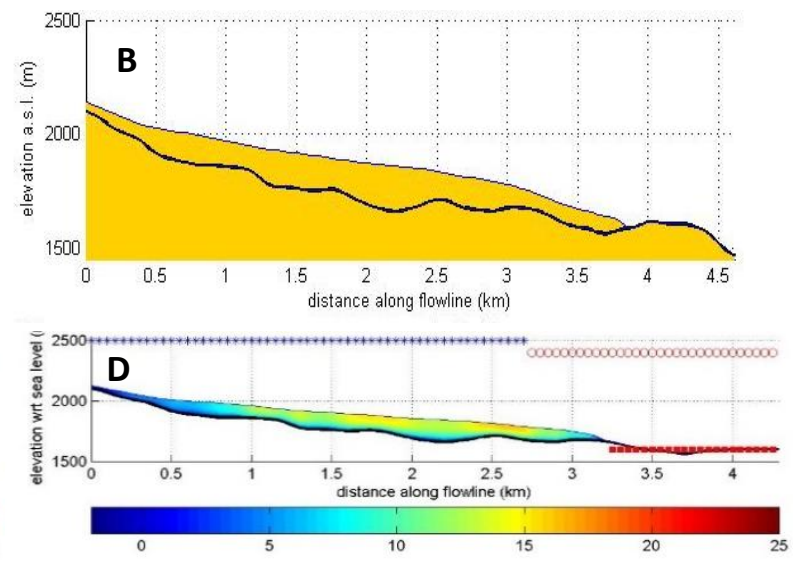

Figure 9. Comparison of the resultant glacier profile and velocities given the same net mass balance for two different bed topographies. Notice that the slight changes in bed topography cause significant changes in the ice velocity. In A and B, the glacier topography is obviously shown, as well as the glacier length. Both $\mathrm{C}$ and $\mathrm{D}$ show velocity profiles.

The two bed profiles are obtained by following a slightly differing flow line along the bed map of Figure 2. The bed shown in figure 9A is taken through the deepest part of the glacier's basin and is the profile ultimately used for this projects' experiments. For the near equilibrium profiles for a same mass balance shown in figure 9, the glaciers show significantly different lengths (figure 9A and B) and differing 
velocity profiles (table 8 ). Besides a maximum difference in ice velocity of $2.3 \mathrm{~m} \mathrm{a}^{-1}$, the velocity peak near the terminus in figure $9 \mathrm{C}$ is more pronounced and extend a greater distance.

Table 8. A comparison of ice velocities from the glaciers in figure 8 illustrating the differences caused by changing the bed topography.

\begin{tabular}{ccc}
\hline $\begin{array}{c}\text { Distance along the flow line } \\
(m)\end{array}$ & $\begin{array}{c}\text { Ice velocity (profile A/C) } \\
\left(\mathrm{m} \mathrm{a}^{-1}\right)\end{array}$ & $\begin{array}{c}\text { Ice velocity (profile B/D) } \\
\left(\mathrm{ma}^{-1}\right)\end{array}$ \\
\hline 632 & 5.9 & 6.1 \\
1044 & 12 & 13.2 \\
1234 & 14.3 & 12.0 \\
1471 & 14.6 & 12.2 \\
1591 & 15.0 & 14.4 \\
1664 & 15.4 & 14.9 \\
1719 & 15.4 & 15.1 \\
2438 & 16.3 & 15.5 \\
2746 & 16.2 & 14 \\
2610 & 15.9 & 15.5 \\
2960 & 12.4 & 11 \\
\hline
\end{tabular}

\subsection{Simulating South Cascade Glacier}

Beginning with a model in equilibrium, we analyze the behavior of South Cascade Glacier by simulating the glacier through three time periods:

1) From $1940-1964$

2) From $1940-2011$

3) From $1890-2011$

The resulting velocities, thickness, and lengths are then compared with existing data. 


\section{A. Simulating 1940 to 1964}

To investigate the short-term influence of calving on South Cascade Glacier, I ran a set of experiments from 1940 to 1964 with 1) a calving model glacier, and 2) a non-calving model glacier. Note that all variables (i.e. mass balance, bed elevation, etc.) are the same for the two simulations. The resulting profiles are shown in figure 10 and 11, and the terminus positions for each experiment are compared in figure 12 and table 9.

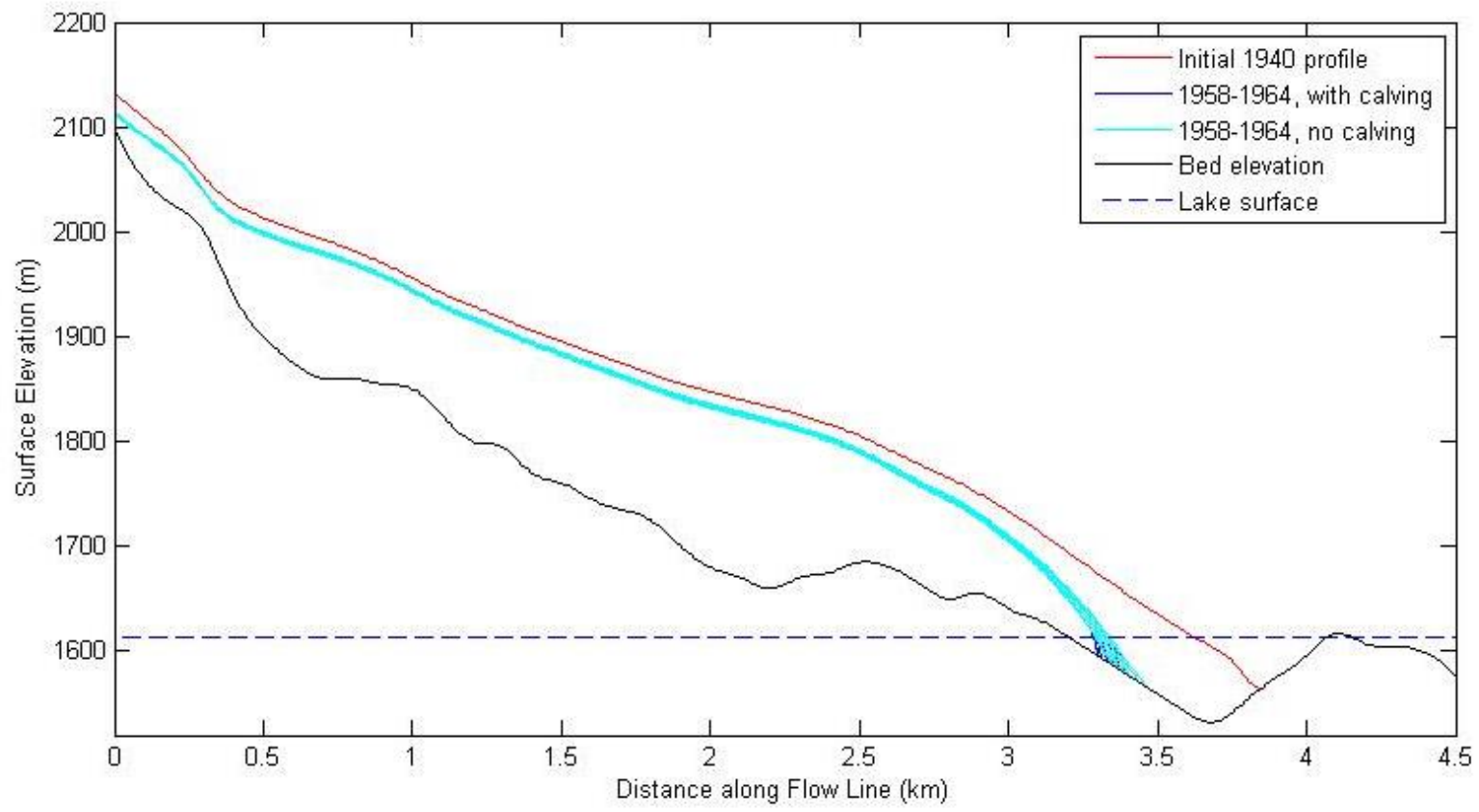

Figure 10. The ice thickness profiles resulting from the 1940-1964 experiments. Note that both the calving and no calving profiles are exactly the same with the exception of the terminus. 


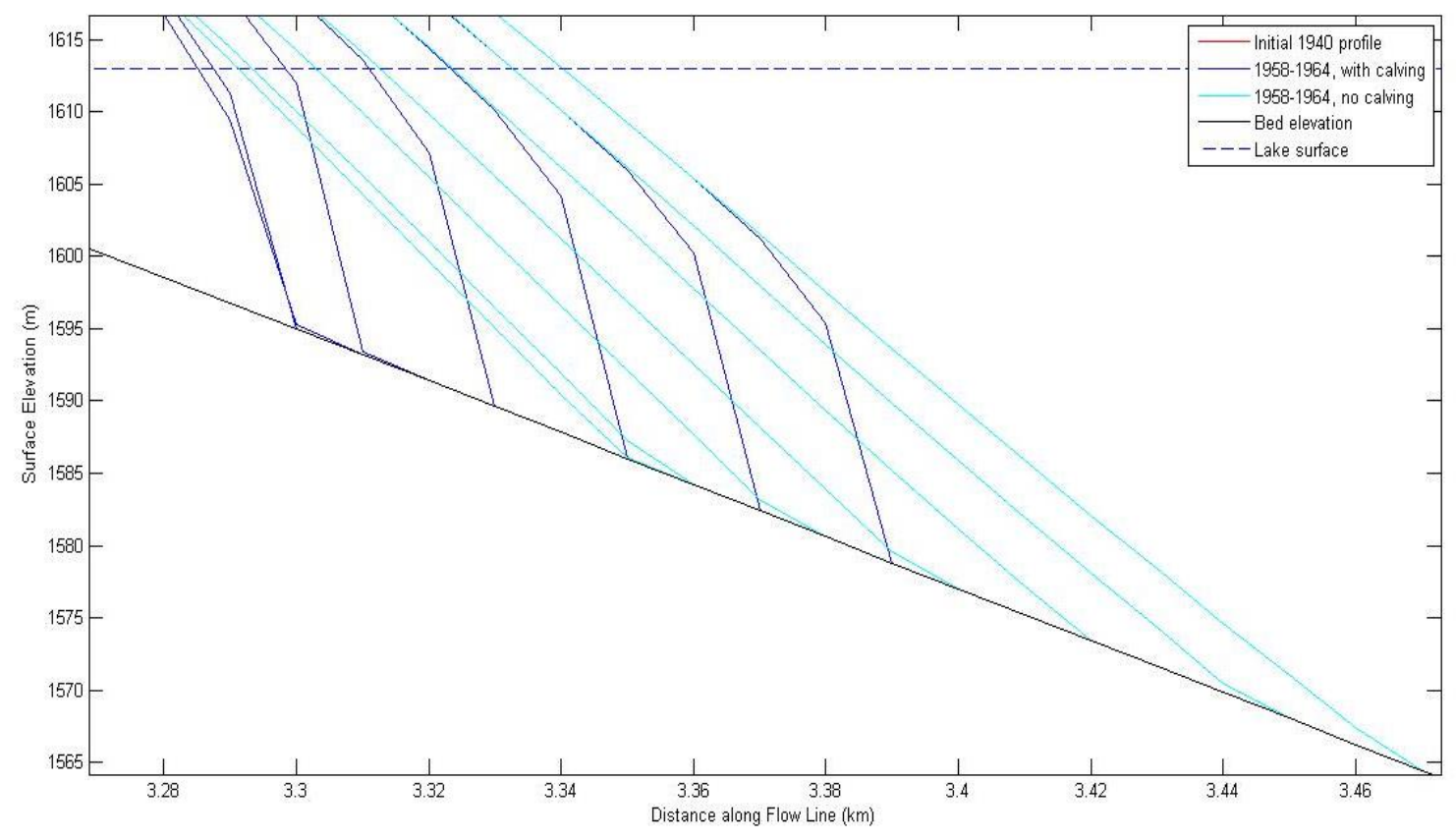

Figure 11. Terminus positions for years 1958 to 1964 for the model glacier with and without calving during the 1940-1964 simulation.

For 1958 to 1964, both calving and non-calving glaciers have exactly the same ice thickness with the exception of the terminus geometry and position (figures 10 and 11). Notice the steep calving front illustrative on the calving glacier (why it is not completely vertical is a result of the nodal spacing of the model). The calving model glacier is consistently shorter than the non-calving glacier through the 7 year time span detailed in figure 11, which is logical since mass is being removed at its terminus through that time. Both simulations approximate the overall trend of the glacier's retreat through 1958 to 1964 , as shown in figure 12 and Table 4. However, the non-calving model glacier appears to approximate the glacier length much more closely than the calving model glacier (Figure ). 


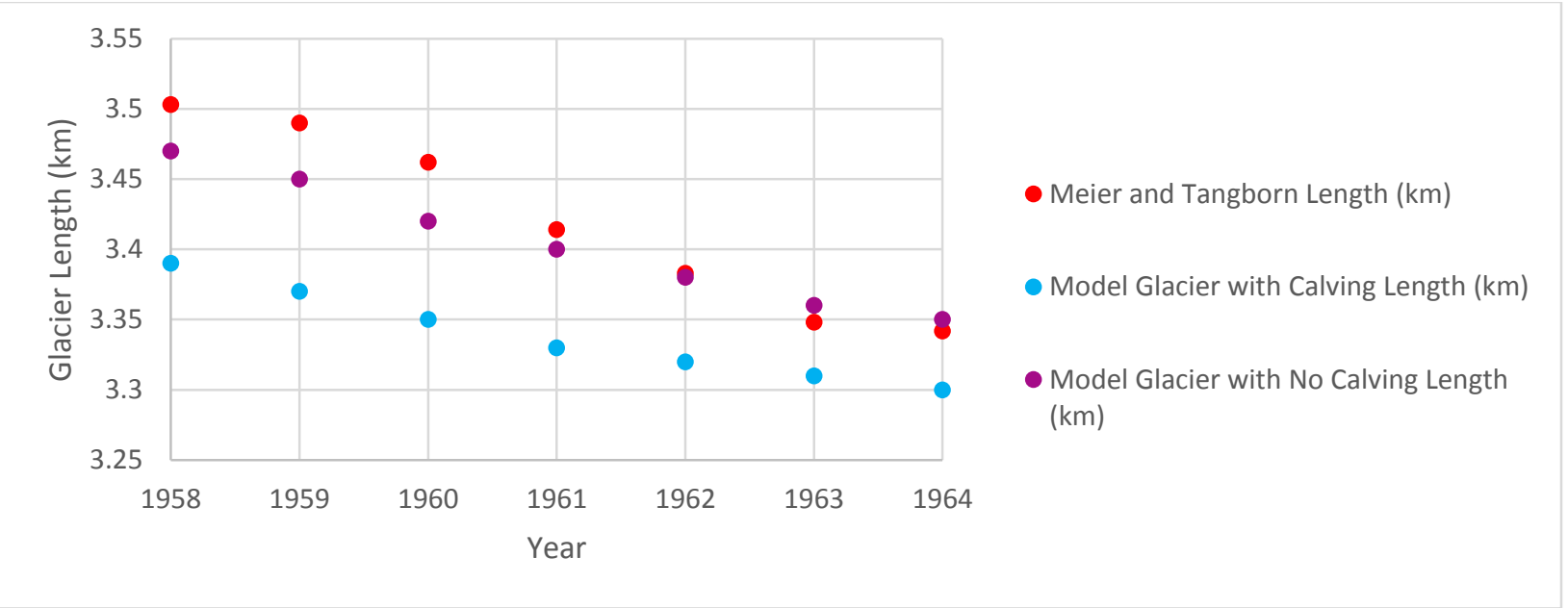

Figure 12. Terminus positions (i.e. glacier length) showing the experimental runs and measurements from Meier and Tangborn (1965).

Table 4. Terminus positions for 1958 to 1964 of Meier and Tangborn (1965) compared with the calving and non-calving model glaciers.

\begin{tabular}{cccc}
\hline Year & $\begin{array}{c}\text { Meier and Tangborn } \\
\text { Length }(\mathrm{km})\end{array}$ & $\begin{array}{c}\text { Model Glacier with Calving } \\
\text { Length }(\mathrm{km})\end{array}$ & $\begin{array}{c}\text { Model Glacier with No Calving } \\
\text { Length }(\mathrm{km})\end{array}$ \\
\hline 1958 & 3.503 & 3.39 & 3.47 \\
1959 & 3.49 & 3.37 & 3.45 \\
1960 & 3.462 & 3.35 & 3.42 \\
1961 & 3.414 & 3.33 & 3.4 \\
1962 & 3.383 & 3.32 & 3.38 \\
1963 & 3.348 & 3.31 & 3.36 \\
1964 & 3.342 & 3.3 & 3.35 \\
\hline
\end{tabular}

The resulting velocity profiles shown in figure 13 are exactly the same except at the terminus. The spike in velocity at the terminus of the calving glacier model is a result of the removal of mass as a result of calving. The sudden removal of ice on the lake side of the glacier causes the modeled ice to suddenly be unobstructed and flow towards the lake side at a higher velocity. 


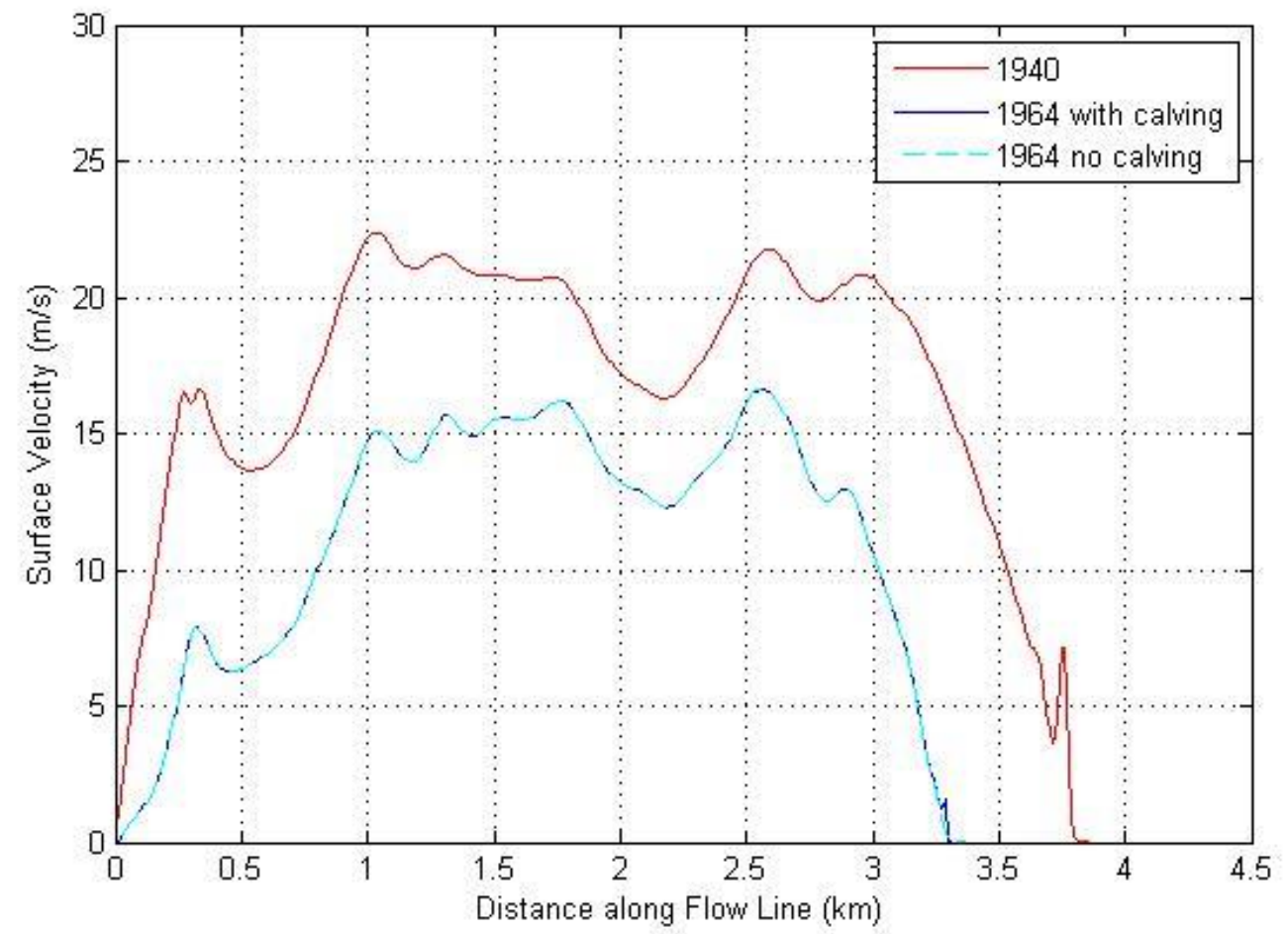

Figure 13. The initial surface velocity profile (1940) and the surface velocity profile for 1964 for calving and non-calving glaciers.

\section{B. Simulating 1940 to 2007}

To determine the longer-term influence of calving on South Cascade Glacier, I ran a second set of experiments from 1940 to 2007 with 1) calving, and 2) no calving. Calving for the calving experiment was implemented from 1940 to 1978. The thickness profile results for both simulations are presented in figure 14 and figure 15 . The model glacier for both simulations thins considerably between 1940 and 2007 and retreats from $3.85 \mathrm{~km}$ to $2.9 \mathrm{~km}$. Differences in the calving and non-calving model glacier terminus positions occur until 1979, when the glacier is just slightly out of the lake. As seen in the last set of experiments, the calving model glacier recedes farther than the non-calving model glacier by 1964 (3.3 $\mathrm{km}$ versus $3.35 \mathrm{~km}$, respectively). However, by 1979, the non-calving model glacier is shorter than the calving model glacier (3.12 $\mathrm{km}$ versus $3.16 \mathrm{~km}$, respectively). By 1994, both model glaciers assume the 
same ice thickness profiles until 2007. For 1994, 2000, and 2007, the calving and non-calving model glaciers are $3.03 \mathrm{~km}, 2.98 \mathrm{~km}$, and $2.93 \mathrm{~km}$ long, respectively.

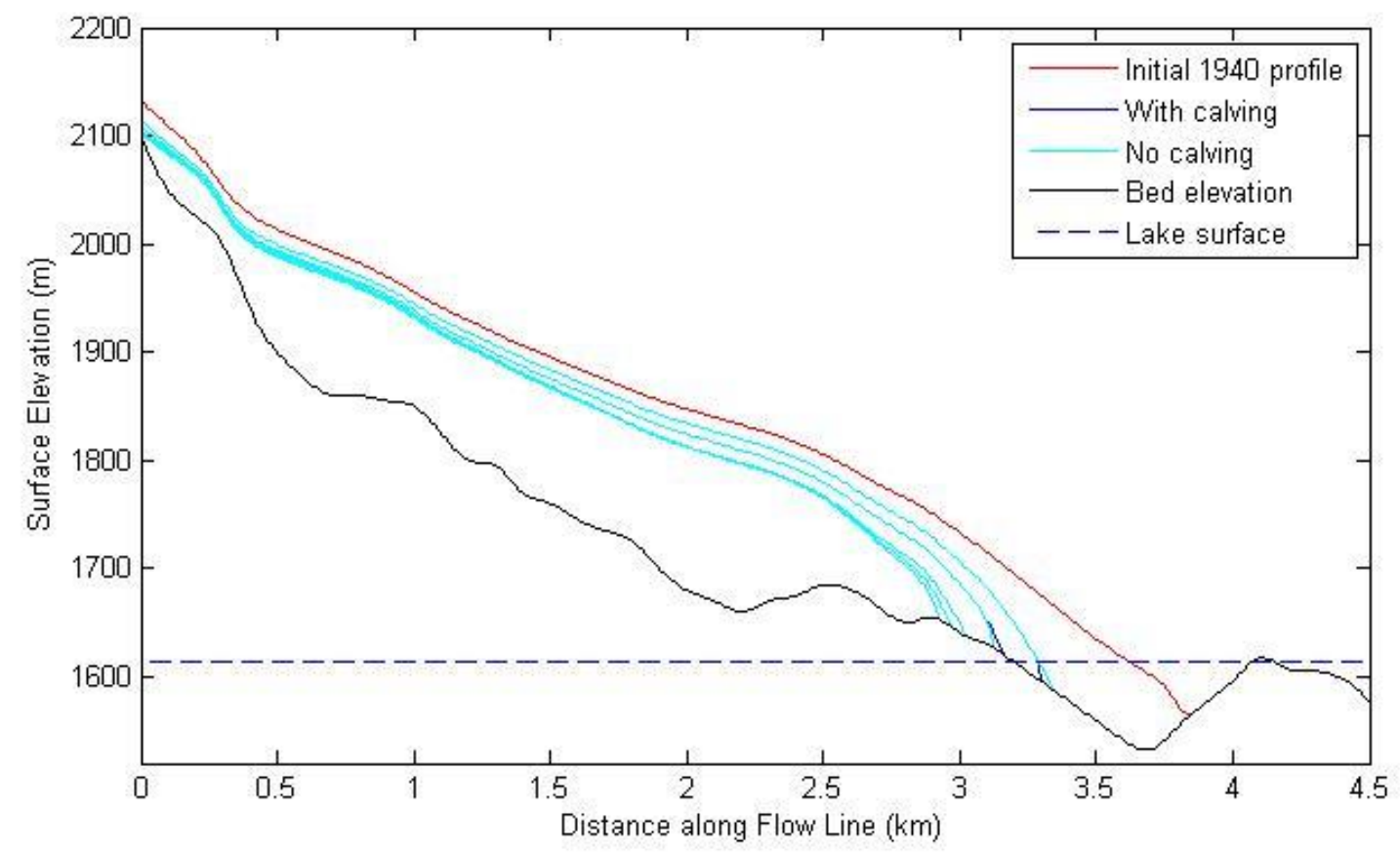

Figure 14. Ice thickness profiles for 1940 (the initial profile), 1964, 1979, 1994, 2000, and 2007 for calving and non-calving model glaciers.

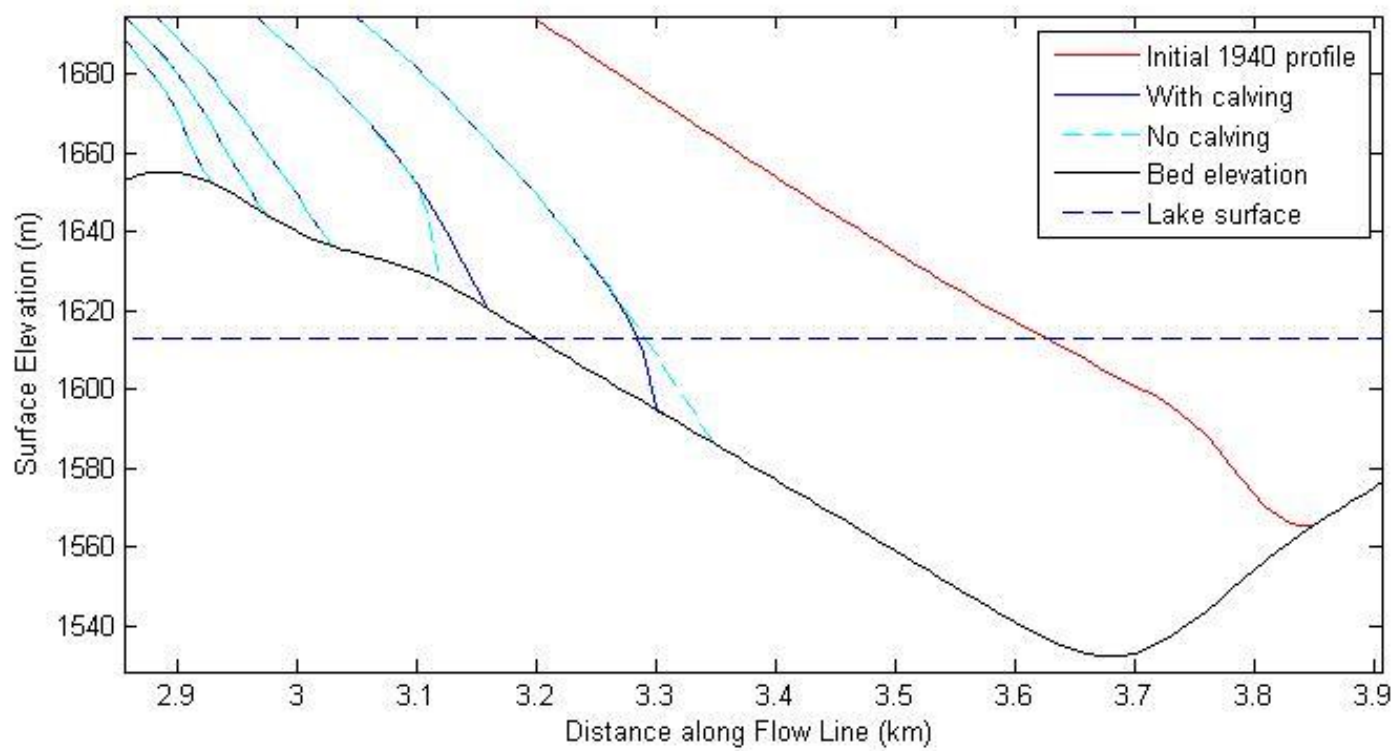

Figure 15. Terminus positions for calving and non-calving glaciers for 1940 (the initial profile), 1964, 1979, 1994, 2000, and 2007, respectively. 
Why is the non-calving model glacier shorter than the calving model glacier in 1979? Why are the subsequent profiles exactly the same? Several factors can possibly account for these observations. For a given climate signal, a glacier will respond in order to come into equilibrium with the new net mass balance. The response times for different glaciers vary. However, for a given glacier, the closer the glacier's profile is to the equilibrium state, the less dramatic its response will be to reach it. For example, if a glacier of length $x$ is several kilometers longer than an equilibrium position for a given climate signal (i.e., warming or higher ELAs), it will retreat, and most likely rapidly (of course there are many other factors to consider; however, let us just consider the general picture). If the glacier had, already, been closer to that equilibrium position, say at length $y$, then it would retreat, but the rate of change may not be as rapid. In relation to South Cascade Glacier, the calving model glacier is shorter than the non-calving model glacier as the glacier exits the lake. With rising ELAs from 1979 to 2007 (figure 16), the equilibrium state dictated by the ELAs is a much shorter glacier than both profiles. Since the calving model glacier is slightly shorter, the glacier may not response with as great of a rate of change of length as the longer, non-calving model glacier. Ultimately, both simulations achieve the same length by 1994 . Through 1994 to 2007, both modeled glaciers have the same length and thicknesses. Several factors may account for the results. Firstly, the ELAs in beginning the 1990s begin to drop comparatively in elevation (figure 16). Secondly, the effects of calving may have had a limited impact on the overall size of the glacier, and the climate-driven response may have overtaken the slight impacts that calving may have had on the glacier. 


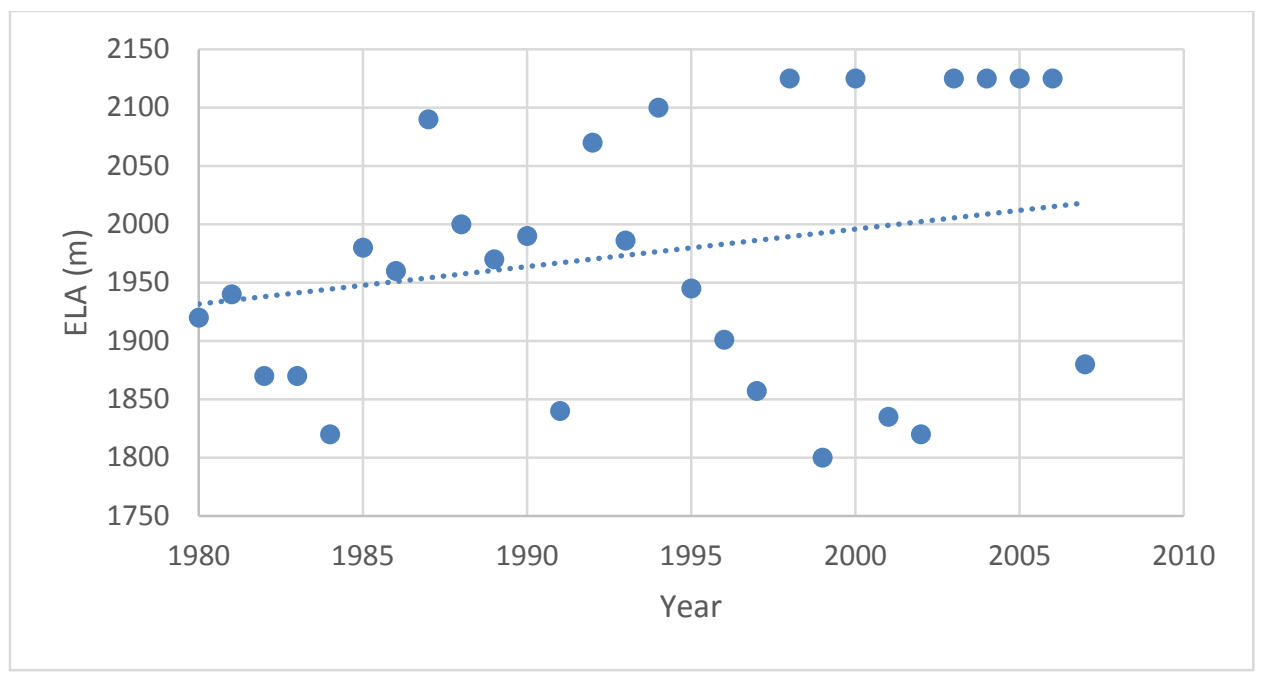

Figure 16. The ELA is, in general, increasing since the glacier receded from the lake basin. Notice the consistently high ELAs beginning towards the end of the 1990s and into the early 2000s.

The velocity profile results obtained from the 1940 to 2007 simulations are presented in figure 17 . The 2007 profiles for the calving and non-calving model glaciers are exactly the same.

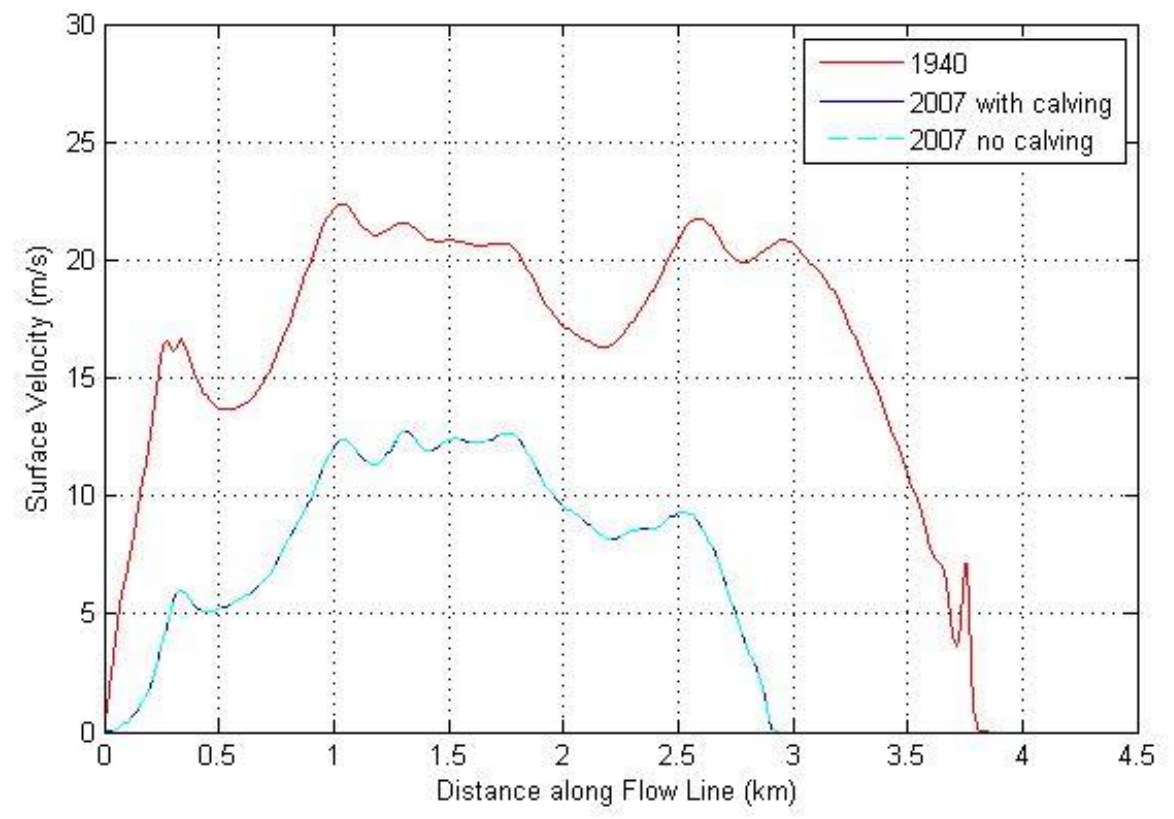

Figure 17. The initial (1940) and 2007 profiles for a calving and non-calving glacier. 


\section{Simulating 1890 to 2007}

In order to place the calving phase of South Cascade Glacier in the context of its entire recession, another set of experiments is presented. The simulations extend from the glacier's Little Ice Age position in 1890 to 2007 with a 1) calving model glacier, and 2) non-calving model glacier. Figure 18 and figure 19 show the ice thickness and terminus position results.

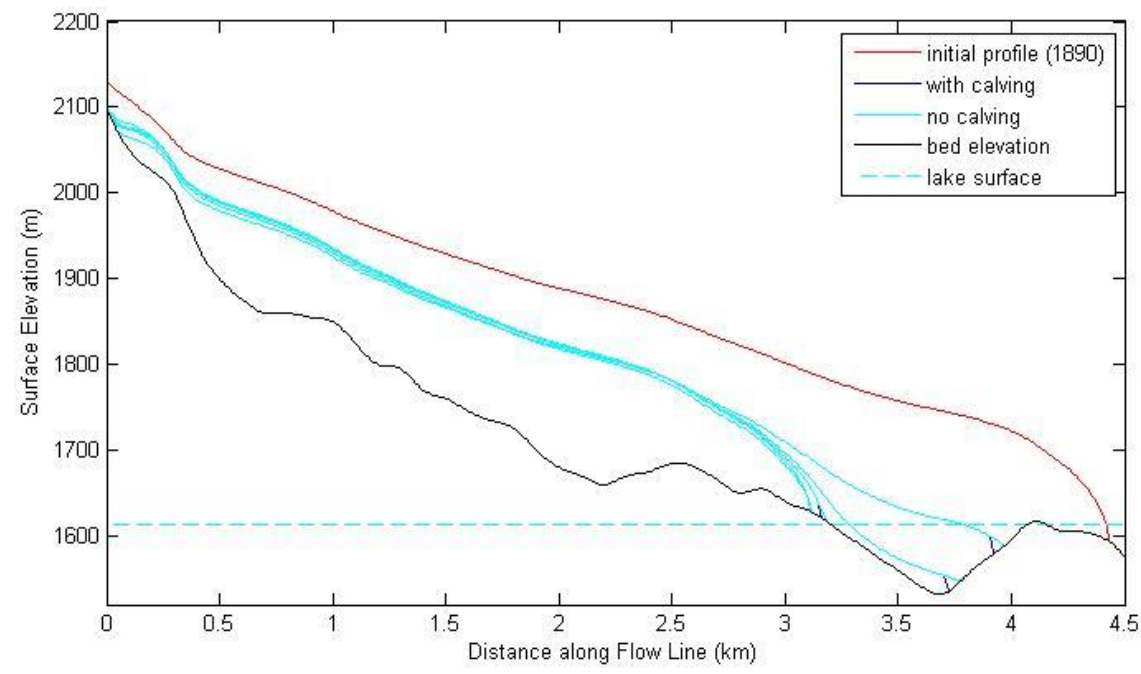

Figure 18. Modeled ice thickness profiles for the years 1890, 1940, 1964, 1979, 1994, and 2007.

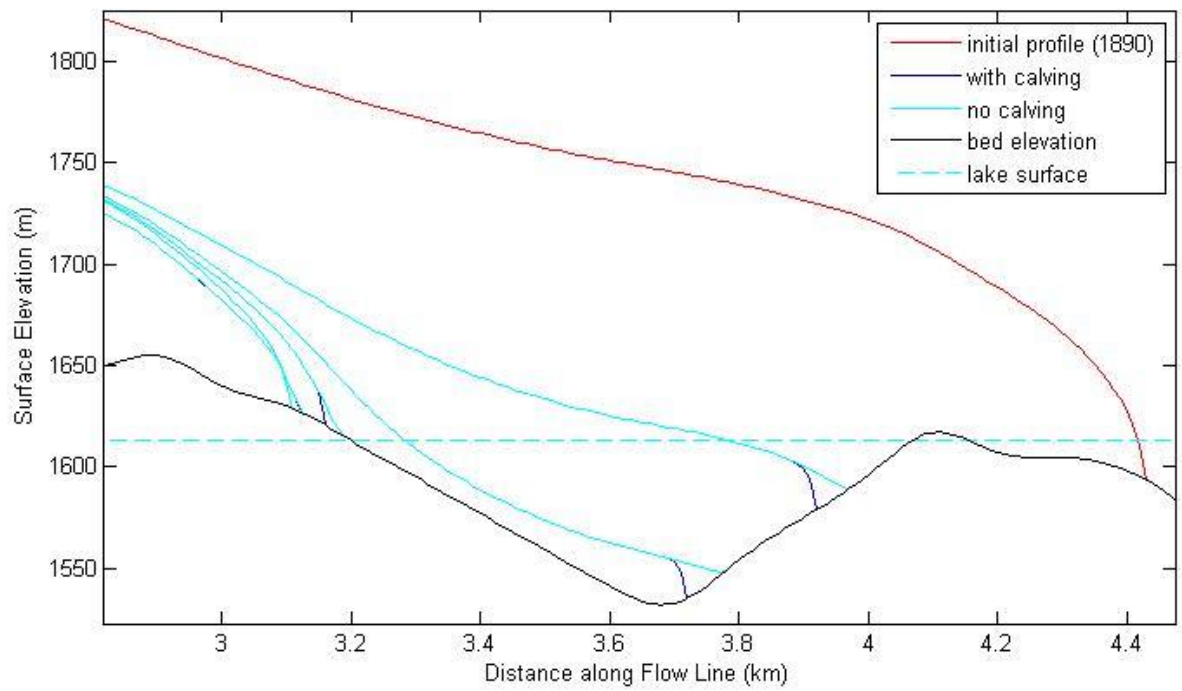

Figure 19. Close-up of Figure showing the modeled terminus positions throughout the recession of South Cascade Glacier at years 1890, 1940, 1964, 1979, 1994, and 2007. 
In general, the model generally simulates the retreat of the glacier from 1890 to 2007 with minor discrepancies. In 1890, the glacier starts at an equilibrium position of $4.45 \mathrm{~km}$ long. By 1940, the calving model glacier has undergone 12 years of calving and is at a position of approximately $3.9 \mathrm{~km}$ along the flow line. The non-calving model glacier is slightly longer (at $4.0 \mathrm{~km}$ ) by 1940 . By 1964, the model calculates the calving glacier as $3.7 \mathrm{~km}$ long and the non-calving model glacier as $3.8 \mathrm{~km}$ long. Note that the 1964 position measured by Meier and Tangborn (1965) is approximately $3.342 \mathrm{~km} \pm 0.005 \mathrm{~km}$. By 1979, both model glaciers are shortly up-valley from the lake, congruent with aerial photography for that year. Here, the calving model glacier is $3.16 \mathrm{~km}$ long, whereas the non-calving glacier is $3.2 \mathrm{~km}$ long Thinning and shortening of the glacier continues and at 1994, both model glaciers have the same profiles and have retreated to $3.13 \mathrm{~km}$ along the flow line. By 2007, both model glaciers thicken slightly and retreat to $3.11 \mathrm{~km}$ along the flow line. The length of South Cascade Glacier in 2007 is approximately 2.9 $\mathrm{km}$, as determined by aerial photography (Bidlake et al., 2010). A comparison of the results from this experiment as well as the 1940 to 2007 experiment, the 1940 to 1964 experiment, and measured records are shown in table 10 .

Table 5. Results of the three main experiments with calving and comparison to field measured, photographed, or projected glacier lengths. Field measurements in 1964 were taken by Meier and Tangborn (1965) and from moraine analysis by Miller (1969), the glacier length in circa 1890 can be approximated. From aerial photographs, the glacier's lengths in 1940, 1979, 1994, and 2007 are visually determined or calculated. Non-calving model results are shown in parenthesis. Calving results are not shown in parenthesis.

\begin{tabular}{|c|c|c|c|c|}
\hline Year & $\begin{array}{l}\text { Measured, Photographed, } \\
\text { or Projected Length (km) }\end{array}$ & $\begin{array}{l}1940 \text { to } 1964 \\
\text { Experiment Results with } \\
\text { Calving }(\mathrm{km})\end{array}$ & $\begin{array}{l}1940 \text { to } 2007 \\
\text { Experiment Results } \\
(\mathrm{km})\end{array}$ & $\begin{array}{l}1890 \text { to } 2007 \\
\text { Experiment Results } \\
(\mathbf{k m})\end{array}$ \\
\hline 1890 & $\sim 4.45$ & - & - & 4.45 \\
\hline 1940 & 3.85 & 3.85 & 3.85 & $3.90(4.00)$ \\
\hline 1964 & 3.34 & $3.3(3.35)$ & $3.30(3.35)$ & $3.70(3.80)$ \\
\hline 1979 & 3.20 & - & $3.15(3.12)$ & $3.16(3.20)$ \\
\hline 1994 & $\sim 3.00$ & - & $3.03(3.03)$ & $3.13(3.13)$ \\
\hline 2007 & $\sim 2.90$ & - & $2.93(2.93)$ & $3.11(3.11)$ \\
\hline
\end{tabular}


The 1890 to 2007 experiment gives the greatest discrepancy of glacier length around 1964 (table 10). As stated previously, an estimated average ELA of $2015 \mathrm{~m}$ was applied from 1890 to 1931. With this ELA, the model calculated a glacier that was approximately the same length as the 1940 profiles used for the other experiments. However, the length is not the main controlling factor in governing subsequent glacier response; in fact, the thickness profile is the more important because it records the complex mass balance history that the glacier has experienced. Therefore, applying a single ELA throughout the years 1890 to 1930 most likely does not mirror the actual ELA fluctuations that the glacier experienced. Therefore, the resulting profile, which "stores" the mass balance history, fails to approximate the South Cascade Glacier at that time. However, with time the model glacier gradually approximates South Cascade Glacier's recession more closely, which is a result of the response time of the model glacier. The model glacier from 1931 onward experiences the fluctuating ELAs that are characteristic of that time, and the model manages to adjust its profile. With increasing time from the beginning of the simulation, the profile has had more time to respond to the mass balances unique to South Cascade Glacier, and has less and less of the "memory" of initial profile or the average ELA applied from 1890 to 1931. ("Memory" is a term imparted by Johannesson et al. (1989) in their examination of the time response of glaciers.) It appears that by 1979 , the glacier does in fact manage to match the measured glacier lengths more closely than previously.

For the 1940 to 2007 experiment, the calving model glacier was longer than the non-calving model glacier in 1979 as stated previously. However, this is not the case for the 1890 to 2007 experiment (table 10). Table 10 also shows that the model glacier from the 1890 to 2007 experiment receded only $0.02 \mathrm{~km}$ from 1994 to 2007, which differs from a $0.10 \mathrm{~km}$ retreat for the 1940 to 2005 simulation. Again, the reason for the differences in both cases is most likely the effect of the "memory" of the glacier's mass balance history.

The velocity profiles for 1890 and 2007 for the last experiment are shown in figure 20 . The maximum velocities of the model glacier have drastically decreased, a result of the thinning and 
shortening of the glacier. Maximum velocity at its LIA position in 1890 is over $25 \mathrm{~m} \mathrm{a}^{-1}$ compared with a maximum velocity of $13 \mathrm{~m} \mathrm{a}^{-1}$ in 2007 , which results in an over $10 \mathrm{~m}^{-1}$ decrease in maximum velocity over a 118 year span.
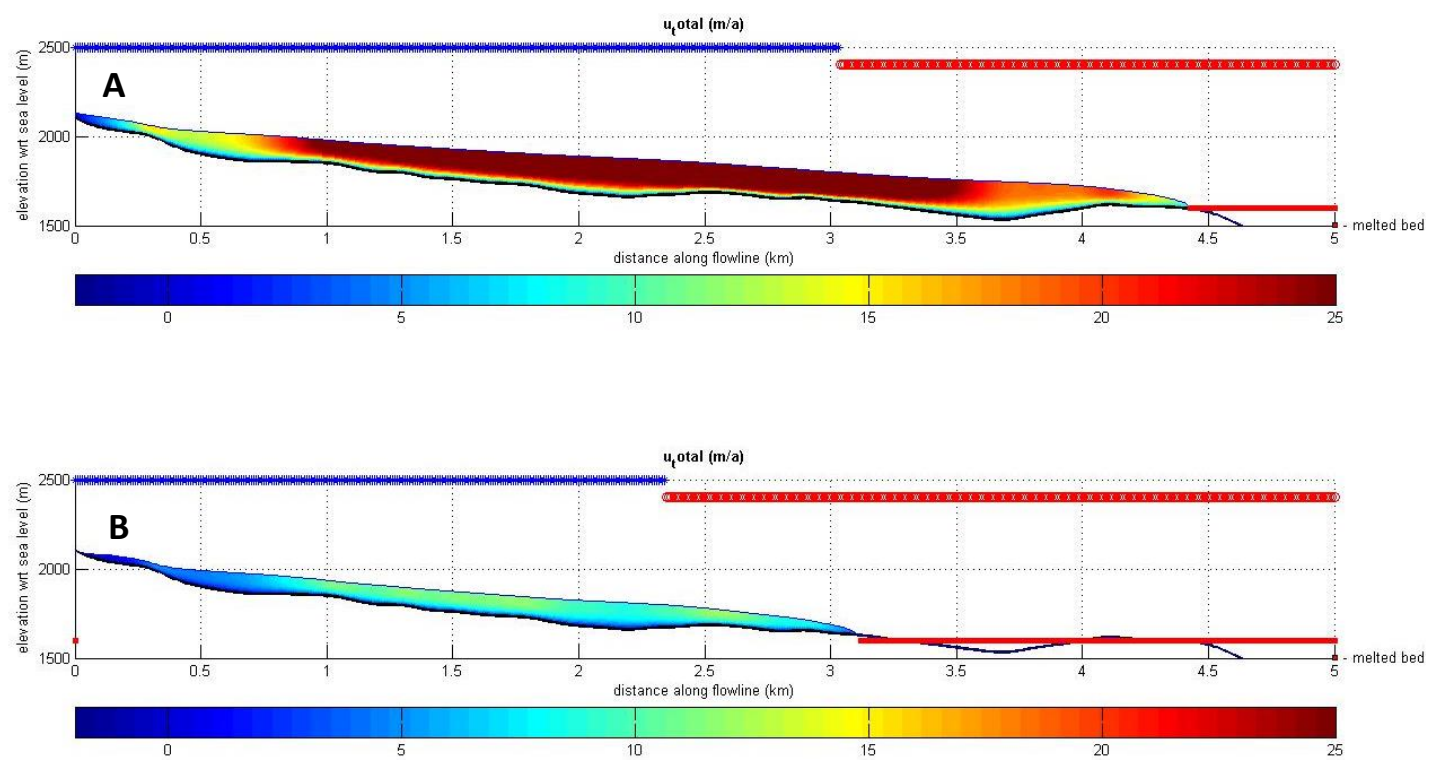

Figure 20. The velocity profiles for South Cascade Glacier in 1890 (A) and in 2007 (B).

\section{Conclusion}

Model calibration showed that smaller nodal spacing improved the approximation of the model South Cascade Glacier velocities to measured velocities of Meier and Tangborn (1965). This is a logical finding, as the greater the number of nodes in a given interval, and thus the number of calculations, will produce greater accuracy; however, it does come at a cost of greater running time because of a necessary reduction in the time step. The model glacier was thinner by approximately $30 \%$, but approximated the velocity, length, and retreat behavior of South Cascade Glacier well. Subsequent adjustments to the model, such as reduction of the flow law parameter $A$, did not improve the fit. We also discovered that the model showed great sensitivity to changes in mass balance and basal elevation. 
According to the experiments from 1940-1964, 1940-2007, and 1890-2007, calving through the proglacial lake had very little influence on the overall length and thicknesses of the glacier, however a more advanced calving model (that accounts for a floating terminus) is necessary to check this result. Small differences in length were observed for calving and non-calving glacier simulations, with the calving glacier overall retreating farther up-valley during the lake-terminating phase. Subsequent adjustment (retreat) of the calving and non-calving glaciers to the same position occurred after the laketerminating phase, ultimately resulting in the two model glaciers being the same length and thickness. Measurements of Meier and Tangborn (1965) are comparably closer to the non-calving model glacier simulation than the calving model glacier simulation from 1958 to 1964 for the first experiment (table 11). However, the calving model glacier approximated Meier and Tangborn (1965) measurements for those years much better than the non-calving model for the 1890-2007 experiment. This shows that the response time of the model glacier is integral in evaluating the results of these experiments, and that the 24 year "spin-up" time span of the first experiment was likely too short to provide accurate results for the year 1964. This concept is especially important to consider since the glacier terminated in the lake starting in 1928, which would generate close to 12 years of calving before 1940. According to the 1940-2007 and 1890-2007 experiments, both calving and non-calving model glaciers ultimately retreated back to the same positions shortly before 15 years after they ceased terminating in the lake, and further assumed the same recession rate until 2007. These results suggest that climatic variations, expressed through the ELA, are more important than the effect of calving on changing the size of South Cascade Glacier. For the future continuation of this study, implementing a more advanced calving model is necessary to verify the results. 


\section{References}

Anslow, F.S., Hostetler, S., Bidlake, W.R., and Clark, P.U., 2008, Distributed energy balance modeling of South Cascade Glacier, Washington and assessment of model uncertainty: Journal of Geophysical Research: Earth Surface, v. 113, p. 2156 - 2202.

Benn, D.I., N.R.J. Hulton, and Mottram, R.H., 2007a, 'Calving laws,' 'sliding laws,' and the stability of tidewater glaciers: Annals of Glaciology, v. 46, p. 123-130.

Benn, D.I., Warren, C.R., and Mottram, R.H., 2007b, Calving processes and the dynamics of calving glaciers: Earth-Science Reviews, v. 82, p. 143-179.

Bidlake, W.R., Josberger, E.G., and Savoca, M.E., 2004, Water, ice, and meteorological measurements at South Cascade Glacier, Washington, balance year 2002: U.S. Geological Survey Scientific Investigations Report 2004-5089.

Bidlake, W.R., Josberger, E.G., and Savoca, M.E., 2005, Water, ice, and meteorological measurements at South Cascade Glacier, Washington, balance year 2003: U.S. Geological Survey Scientific Investigations Report 2005-5210.

Bidlake, W.R., Josberger, E.G., and Savoca, M.E., 2007, Water, ice, and meteorological measurements at South Cascade Glacier, Washington, balance year 2004 and 2005: U.S. Geological Survey Scientific Investigations Report 2007-5055.

Bidlake, W.R., Josberger, E.G., and Savoca, M.E., 2010, Modeled and measured glacier change and related glaciological, hydrological, and meteorological conditions at South Cascade Glacier, Washington, balance and water years 2006 and 2007, U.S. Geological Survey Scientific Investigations Report 2010-5143.

Fountain, A.G., 1989, The storage of water in, and hydraulic characteristics of, the firn of South Cascade Glacier, Washington State, USA: Annals of Glaciology, v. 13, p. 69-75.

Fountain, A.G., 1993, Geometry and flow conditions of subglacial water at South Cascade Glacier, Washington State, USA: an analysis of tracer injections: Journal of Glaciology, v. 131, p. 143-156.

Fountain, A.G., 1994, Borehole water-level variations and implications for the subglacial hydraulics of South Cascade Glacier, Washington State, USA: Journal of Glaciology, v. 40, 293-304.

Fountain, A.G., 2015, Interview by author, Portland State University.

Hooke, R.L.B., 2005, Principles of glacier mechanics: Cambridge University Press, 398 p.

Johannesson, T., Raymond, C.F., and Waddington, E.D., 1989, A simple method for determining the response time of glaciers: Glacier fluctuations and climatic change, Springer, Netherlands, p. 343-352.

Josberger, E.G., Bidlake, W.R., March, R.S., and O'Neel, S., 2009, Fifty-year record of glacier change reveals shifting climate in the Pacific Northwest and Alaska, USA: U.S. Geological Survey Fact Sheet 2009-3046. 
Krimmel, R.M., 1993, Mass balance, meteorological, and runoff measurements at South Cascade Glacier, Washington, 1992 balance year: U.S. Geological Survey Open-File Report 93-640.

Krimmel, R.M., 1994, Runoff, precipitation, mass balance, and ice velocity measurements at South Cascade Glacier, Washington, 1993 balance year: U.S. Geological Survey Open-File Report 94-4139.

Krimmel, R.M., 1995, Water, ice, and meteorological measurements at South Cascade Glacier, Washington, 1994 balance year: U.S. Geological Survey Open-File Report.

Krimmel, R.M., 1996, Water, ice, and meteorological measurements at South Cascade Glacier, Washington, 1995 balance year: U.S. Geological Survey Open-File Report 96-4174.

Krimmel, R.M., 1997, Water, ice, and meteorological measurements at South Cascade Glacier, Washington, 1996 balance year: U.S, Geological Survey Open-File Report 97-4143.

Krimmel, R.M., 1998, Water, ice, and meteorological measurements at South Cascade Glacier, Washington, 1997 balance year: U.S, Geological Survey Open-File Report 98-4090.

Krimmel, R.M., 1999, Water, ice, meteorological, and speed measurements at South Cascade Glacier, Washington, 1998 balance year: U.S, Geological Survey Open-File Report 99-4049.

Krimmel, R.M., 2001, Water, ice, meteorological, and speed measurements at South Cascade Glacier, Washington, 1999 balance year: U.S, Geological Survey Open-File Report 00-4265.

Krimmel, R.M., 2002, Water, ice, meteorological, and speed measurements at South Cascade Glacier, Washington, 2000-01 balance years: U.S, Geological Survey Open-File Report 02-4165.

Maohuan, H., 1990, On the temperature distribution of glaciers in Cidna: Journal of Glaciology, v. 36, p. $210-216$.

McCabe, Jr., and Fountain, A.G., 1995, Relations between atmospheric circulation and mass balance of South Cascade Glacier, Washington, USA: Arctic and Alpine Research, v. 32, p. 64-72.

Meier, M.F., 1958, Research on South Cascade Glacier: The Mountaineer, v. 51, p. 40-47.

Meier, M.F., and Tangborn, W.V., 1965, Net budget and flow of South Cascade Glacier, Washington: Journal of Glaciology, v. 5, p. 547-566.

Meier, M.F., Tangborn, W.V., Mayo, L.R., and Post, A., 1971, Combined ice and water balances of Gulkana and Wolverine Glacier, Alaska, and South Cascade Glacier, Washington, 1965 and 1966 hydrologic years: U.S. Geological Survey Professional Paper 715-A.

Meier, M.F., Dyuorgerov, M.B., Rick, U.K., O’Neel, S, Pfeffer, W.T., Anderson, R.S., Anderson, S.P., Glazovsky, A.F., 2007, Glaciers dominate eustatic sea-level rise in the $21^{\text {st }}$ century: Science, v. 317., p. 1064-1067.

Nye, J.F., 1960, The response of glaciers and ice-sheets to seasonal and climatic changes: Proceedings of the Royal Society Series A, v. 256, p. 559-584.

Oerlemans, J., 2001, Glaciers and climate change: Rotterdam, Netherlands A.A. Balkema Publishers, $160 \mathrm{p}$. 
Oerlemans, J., Anderson, B., Hubbard, A., Huybrechts, P., Joannesson, T., Knap, W.H., Schmeits, M., Stroven, A.P., Van de Wal, R.S.W., Wallinga, J., and Zuo, Z., 1998, Modelling the response of glaciers to climate warming: Climate Dynamics, v. 14, 267-274.

Parizek, B.R., 2000, Thermomechanical flowline model for studying the interactions between ice sheets and the global climate system: Master's Thesis, Pennsylvania State University.

Parizek, B.R., Alley, R.B., and MacAyeal, D.R., 2005, The PSU/UofC finite-element thermomechanical flowline model of ice sheet evolution: Cold Regions Science and Technology, v. 42, p. $145-168$.

Pelto, M.S., 2006, The current disequilibrium of North Cascade glaciers: Hydrological Processes, v. 20, p. 769-779.

Pelto, M.S., and Hedlund, C., 2001, Terminus behavior and response time of North Cascade glaciers, Washington, USA: Journal of Glaciology, v. 47, p. 497-506.

Rassmussen, L.A., 2009, South Cascade Glacier mass balance, 1935-2006: Annals of Glaciology, v. 50, p. $215-220$.

Rassmussen, L.A., and Conway, H., 2001, Estimating South Cascade Glacier (Washington, U.S.A) mass balance from distant radiosonde and comparison with Blue Glacier: Journal of Glaciology, v. 47, p. 579-588.

Rassmussen, L.A., and Conway, H., Using upper-air conditions to estimate South Cascade Glacier (Washington, U.S.A.) summer mass balance: Journal of Glaciology, v. 49, p. 456-462

Skvarca, P., De Angelis, H., Naruse, R., Warren, C.R., and Aniya, M., 2002, Calving rates in fresh water: new data from southern Patagonia: Annals of Glaciology, v. 34, p. 379-384.

Tanborn, W.V., 1980, Two models for estimating climate-glacier relationships in the North Cascades, Washington, U.S.A.: Journal of Glaciology, v. 25, p. 3-21.

Tangborn, W.V., 1999, A mass balance model that uses low-altitude meteorological observations and the area-altitude distribution of a glacier: Geografiska Annaler, v. 81, p. $753-765$.

USGS (United States Geological Survey), 2015, USGS Glacier Studies: South Cascade Glacier, < http://www.usgs.gov/climate_landuse/clu_rd/glacierstudies/scascade.asp >

Warren, C.R., 1994, Freshwater calving and anomalous glacier oscillations: recent behaviour of Moreno and Ameghino Glaciers, Patagonia: The Holocene, v. 4, p. 422 - 429.

Warren, C.R., Greene, D.R., and Glasser, N.F., 1995, Glaciar Upsala, Patagonia: rapid calving retreat in freshwater: Annals of Glaciology, v. 21, p. 311-316.

Warren, C.R., and Kirkbride, M.P., 2003, Calving speed and climatic sensitivity of New Zealand lakecalving glaciers: Annals of Glaciology, v. 36, p. 173-178. 